\title{
Migration and Imperfect Labor Markets: Theory and Cross-country Evidence from Denmark, Germany and the UK*
}

\author{
Herbert Brücker ${ }^{\dagger} \quad$ Andreas Hauptmann ${ }^{\ddagger} \quad$ Elke J. Jahn ${ }^{\S}$ \\ Richard Upward
}

This version: August 8, 2013

\begin{abstract}
We investigate the labor market effects of immigration in Denmark, Germany and the UK, three countries which are characterized by considerable differences in labor market institutions and welfare states. Institutions such as collective bargaining, minimum wages, employment protection and unemployment benefits affect the way in which wages respond to labor supply shocks, and, hence, the labor market effects of immigration. We employ a wage-setting approach which assumes that wages decline with the unemployment rate, albeit imperfectly. We find that wage flexibility is substantially higher in the UK compared to Germany and Denmark. As a consequence, immigration has a much larger effect on the unemployment rate in Germany and Denmark, while the wage effects are larger in the UK. Moreover, the elasticity of substitution between natives and foreign workers is high in Denmark and particularly low in Germany. Thus, the pre-existing foreign labor force suffers more from further immigration in Germany than in Denmark.
\end{abstract}

Keywords: immigration, unemployment, wages, labor markets, panel data, comparative studies.

JEL code: F22, J31, J61.

\footnotetext{
${ }^{*}$ The authors are grateful to Charlène Hacquebart, who provided excellent reseach assistence. Frèdèric Docquier, the participants of the annual meeting of the European Society of Labour Economists (EALE), September 2013, of the European Society of Population Economics (ESPE), June 2012, of the annual meeting of the Verein für Socialpolitik, September, 2011, of the TEMPO conference in Vienna, October 2011, and of the research seminar of the economic department at the University Lovain-la-Neuve, October 2011, provided valuable comments. The authors gratefully acknowledge financial support from the "TEMPO" project funded by the NORFACE program.

${ }^{\dagger}$ University of Bamberg, IAB Nürnberg, CrEAM, London, and IZA Bonn, herbert.bruecker@iab.de.

${ }^{\ddagger}$ IAB Nünberg, andreas .hauptmann.iab.de

${ }^{\S}$ IAB Nürnberg, Århus University, and IZA Bonn, elke.jahn@iab.de.

ฯ University of Nottingham, richard.upward@nottingham.ac.uk.
} 


\section{Introduction}

Concerns that immigrants take jobs away from natives and reduce their wages are widespread in most European countries. The current financial and economic crisis has further fueled these fears and raised sentiments against immigration. The impacts of immigration on labour markets are also subject of long-standing controversies in the academic literature. While a substantial number of studies, mainly coming from the US and Europe, finds no discernible effects on natives' wages and employment opportunities (Card, 1990, 2001, 2005; Dustmann et al., 2005; Pischke and Velling, 1997) ${ }^{1}$, Borjas et al. $(1996,1997)$, Borjas (2003) and Aydemir and Borjas (2007) provide evidence that the impact of immigration on wages and unemployment may be substantial and argue that large parts of the literature systematically tend to underestimate the labour market effects of immigration. These controversial findings can be traced back to differences in the theoretical frameworks, the specification of empirical models and different identification strategies.

In this paper we contribute to this literature by taking a fresh look at the effects of immigration on employment and wages using a theoretical and empirical framework which considers imperfect labor markets. Such labor markets are characterized by the presence of labor market institutions, that is systems of laws, bargaining rules, unemployment benefits and labor market programs, that shape the behavior of workers and employers. These institutions differ considerably across countries. We therefore apply a cross-country approach to analyze whether, and to what extent, the labor market effects of immigration vary between countries depending on their institutional settings.

Based on a theoretical framework which assumes that wages adjust only imperfectly to labor supply shocks, we use micro data from Denmark, Germany and the UK to estimate the wage and employment effects of immigration in those countries. All three countries have seen a substantial influx of migrants during the last two decades. From 1990 to 2010, cumulative net migration amounted to $8.6 \%$ of the population in Germany, $4.3 \%$ in Denmark and $4.1 \%$ in the UK (World Bank, 2013). While migration to Germany surged following the fall of the Iron Curtain, net migration to Denmark and the UK has also accelerated substantially since the turn of the century, partly as a consequence of the European Union's Eastern enlargement. In the course of the financial and economic crisis, net migration figures have soared in Germany, but declined in Denmark and the UK relative to the 2008 level.

The institutions of the labor market and the welfare state of these three countries are characterized by different institutional settings, as Table 1 illustrates. The so-called Danish 'flexicurity' system features relatively weak employment protection and a high rate of hirings and firings, but high transfers to unemployment households (Anderson and Svarer, 2007). Moreover, industrial relations are characterized by a extremely high

\footnotetext{
${ }^{1}$ See also the meta-studies by Longhi et al., 2005, 2006, 2008.
} 
coverage of collective bargaining agreements and union membership density in Denmark. Competition in national product markets as well as exposure to international competition is high, suggesting that rents at the firm level are rather low. Finally, taxes are high and progressive in Denmark, which in turn affects wage-setting for different groups in the labor market in different ways (Lockwood et al., 2000).

Table 1: Institutional indicators for Denmark, Germany and the UK, 2010 or latest available year

\begin{tabular}{lrrr}
\hline & Denmark & Germany & UK \\
\hline Collective bargaining coverage in $\%^{\mathrm{a}}$ & 82 & 63 & 35 \\
Union density in $\%^{\mathrm{b}}$ & 68.5 & 18.6 & 26.4 \\
& & & no \\
Legal minimum wage & no & yes
\end{tabular}

Net income of unemployed household as \% of average employed net income ${ }^{\mathrm{c}}$

$\begin{array}{llll}\text { Single, no children } & 83 & 59 & 55\end{array}$

$\begin{array}{llll}\text { Married, one earner, two children } & 88 & 80 & 77\end{array}$

Net personal marginal tax rate $\%^{\mathrm{d}}$

$\begin{array}{llll}67 \% \text { of average earnings } & 42.56 & 50.53 & 31.00\end{array}$

$\begin{array}{llll}100 \% \text { of average earnings } & 49.43 & 56.78 & 31.00\end{array}$

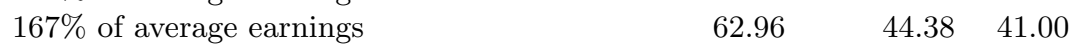

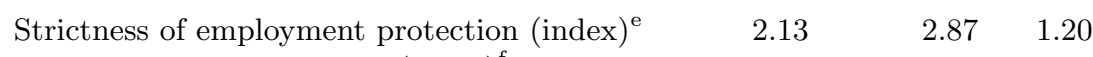

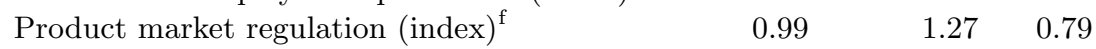

$\begin{array}{llll}\text { Import penetration (in \% of GDP) } & \text { g } & 54 & 44\end{array}$

$\begin{array}{llll}\text { Export propensity (in \% of GDP })^{\mathrm{h}} & 50 & 46 & 29\end{array}$

Net migration $1990-2010$ as \% of population ${ }^{\mathrm{i}} \quad 4.3 \quad 8.6 \quad 4.2$

${ }^{a}$ Collective bargaining coverage corresponds to wage and salary earners covered by collective wage contracts divided by all wage and salary earners. Source: OECD (2011).

${ }^{\mathrm{b}}$ Union density corresponds to the ratio of wage and salary earners that are trade union members divided by all wage and salary earners. Source: OECD (2013).

${ }^{\mathrm{c}}$ Measured at $67 \%$ of average earnings level. The ratio of the net income of unemployed to employed households considers all types of benefits made available to non-wage earners compared to wage earners as well as all taxes for different household types. Source: OECD (2011).

d Principal earner, single household, no child, 2010. Source: OECD (2011).

e See Venn (2009) for the calculation of the employment protection indicator.

${ }^{\mathrm{f}}$ Product market regulation index measures the level by which policies inhibit competition. Source: OECD (2013).

$\mathrm{g}$ The import penetration rate is measured as the ratio of imports to GDP. Source: OECD (2011).

$\mathrm{h}$ The export propensity rate is measured as the ratio of exports to GDP. Source: OECD (2011).

i Source: World Bank (2013).

Germany is the archetypal example of a "continental" European welfare state, where employment protection is strict and welfare benefits are relatively high. The level of employment protection is significantly higher than in Denmark and the UK, while unemployment benefits are below those in Denmark, but above those of the UK. Union density 
is relatively low, but Germany is still characterized by an intermediate coverage of collective bargaining agreements. Moreover, many employers not officially participating in collective bargaining informally apply the contents of collective agreements in their firms. National product market competition is more strongly regulated than in Denmark or the UK, but exposure to international competition is, for a country of this size, high.

Finally, the United Kingdom is characterized by weak employment protection and, relative to the other two countries, low unemployment benefits. The UK typically has a low coverage of collective bargaining agreements and an intermediate level of union membership. In contrast to the other two countries, a legal minimum wage exists in the UK. While national product market competition is strong, exposure to international competition is weak compared to the other two countries.

All these institutional dimensions - the type and effectiveness of collective wage bargaining, the system of unemployment benefits, the system of taxes, the level of employment protection and the regulation of product markets - affect the wage-setting mechanism, the reservation wage and the scope for bargaining, which in turn have an impact on the responsiveness of wages to labor supply shocks. A comparative analysis of these three countries therefore promises new insights into the impact of immigration.

Our theoretical framework derives the wage and employment effects of immigration from a wage-setting approach (e.g. Layard and Nickell, 1986; Layard et al., 2005). A similar framework has been recently adopted for an empirical investigation of the labour market effects of migration by Brücker and Jahn (2011) and Felbermayr et al. (2010). This approach rests on the empirically supported assumption that wages respond to changes in the unemployment rate, albeit imperfectly. The elasticity between wages and unemployment depends on the wage-setting mechanism, other labor market institutions which affect the reservation wage and the value of the outside option, and competition in product markets which determines inter alia the scope for wage bargaining or efficiency wages. Thus, the elasticity between wages and unemployment reflects the different institutional features which characterize the three countries we investigate. In our empirical application of this approach we assume that the elasticity of this wage-setting curve varies across different types of workers.

Once wages are fixed, firms adjust their employment in a way which maximizes their profits. Applying this right-to-manage assumption - which in our view reasonably captures industrial relations in the three countries we investigate - we can derive the labor demand of firms by using a production function approach. Having estimated the elasticities of the wage-setting curves and the elasticities of substitution between different types of labor, we can solve for the wage and employment effects of immigration simultaneously and simulate the labor market effects of immigration for different groups.

The production function approach was pioneered by Grossman (1982) and Borjas (1987) in the immigration literature and experienced a renaissance since the seminal pa- 
pers by Borjas (2003) and Ottaviano and Peri (2012). ${ }^{2}$ Analogous to this literature we approximate production technologies by a nested CES function, which distinguishes labor by education, experience and national origin. Relying on similar assumptions about production technologies as other structural estimation approaches is in our view a strength, since it makes our findings at least partially comparable.

Nevertheless, it is important to understand the differences between our model and estimation strategy and the standard approaches in this strand of the literature: Borjas (2003) (in the structural part of his paper), Ottaviano and Peri (2012) and others derive the wage effects of immigration from a framework where labour supply is assumed to be exogenous and inelastic. This assumption inter alia rules out involuntary unemployment which is an ubiquitous phenomenon, at least in the European context. ${ }^{3}$ In contrast, we replace a standard labour supply function by a set of wage-setting equations where wages are explained by the unemployment rate, and - following the nested structure of the production function - numerous labour demand equations.

Our theoretical framework has important consequences for the identification strategy in this paper. Both the wage-setting equations and the labor demand equations are affected by simultaneity bias. The simultaneity problem arises in the wage setting equations since an unobserved shock to the wage will — via the demand curve - raise unemployment, and this will bias the estimate of the (assumed negative) coefficient towards zero. Suitable instruments should be therefore exogenously correlated with the unemployment rate without affecting the wage directly. Following the literature we use instruments capturing exogenous export demand and sectoral technology shocks.

Analogously, the labour demand equations suffer from a simultaneity problem if an unobserved shock to labour demand, via the wage-setting curve, raises the wage and, thus, bias the estimated coefficient towards zero. A suitable instrument is thus a variable which affects wages without directly affecting labour demand. We therefore use instruments which affect the reservation wage, for example household composition or the household income of unemployed individuals. The reservation wage should affect the wage rate, but not directly labour demand.

Thus, the use of an imperfect labour market framework leads to a different estimation strategy compared to a framework which treats labour supply as exogenous and inelastic. Nevertheless, our approach also shares many features with the traditional literature, i.e. the nested structure of the production function and the respective classification of workers by education, experience and national origin. These classification decisions are often disputed; see the contributions and comments by Borjas et al. (2012), Card (2012),

\footnotetext{
${ }^{2}$ Other important contributions are Aydemir and Borjas (2007), D'Amuri et al. (2010)and Manacorda et al. (2012).

${ }^{3}$ Some of the papers above also supplement their analysis by employment regressions in order to address the effects of immigration on unemployment. However, the theoretical framework analysing the wage impact is at least implicitly derived from a framework with clearing labour markets and inelastic labour supply.
} 
Dustmann and Preston (2012), Ottaviano and Peri (2012) and Manacorda et al. (2012) in the Journal of the European Economic Association. Most controversial is the extent to which natives and migrants in particular education and experience classes are close substitutes. From a policy perspective this is an important issue because the distributional effects of immigration are largely affected by the elasticity of substitution between natives and immigrants. We examine this issue by applying different classifications of education and experience groups, and by using different weights.

Our contribution can be considered to be complementary to the large literature which attempts to estimate the wage and employment effects of immigration directly (Altonji and Card, 1991; Borjas et al., 1996; Pischke and Velling, 1997; Dustmann et al., 2005; Glitz, 2012; Friedberg and Hunt, 1995, for a review). The most common approach in this literature is to use the variation in migration rates across geographical areas, in which the wage or employment rate of natives in a given location is regressed on the relative quantity of immigrants in that same area, with appropriate controls. One of the main difficulties of this strategy arises from immigrants' potentially endogenous choice of location. Many researchers use therefore either experimental- or quasi-experimental evidence (e.g. Card, 1990; Glitz, 2012; Kugler and Yuksel, 2009), or instrumental variable estimation strategies (e.g. Dustmann et al., 2005; Pischke and Velling, 1997). However, it is still possible that this approach fails to allow for other factors which might bias results, such when capital movements, trade or natives' labor mobility spread the effects of immigration to other regions. ${ }^{4}$ Moreover, the spatial correlation approach enables one only to identify the partial effects of immigration rather than the cross effects between different segments of the labor market. Nevertheless, the direct approach imposes less structure on the estimation equations and the outcomes depend therefore less on theoretical assumptions which remain somewhat arbitrary. In this sense, the findings of both strands of the literature should reinforce each other.

Another contribution of our paper is the use of a comparative approach. While there are numerous single-country studies which apply both structural approaches and direct estimates of the wage and employment effects of immigration, these studies typically differ in their methodological approaches, the specifications of the estimated equations, the treatment of the data and the time periods covered. There are therefore severe limitations in the comparability of the findings. One of the few exceptions in the literature is the cross-country study by Aydemir and Borjas (2007), which analyzes the wage effects of immigration in Canada, Mexico and the US, employing a production function framework and using disaggregated micro data. Nevertheless, due to data limitations the time periods covered by this study still differ somewhat across countries.

Our empirical analysis is based on micro data sets in Denmark, Germany and the UK which provide annual observations. These data are derived from social security records

\footnotetext{
${ }^{4}$ See Borjas (2003) and Borjas et al. (1997), for controversial evidence Card (2001, 2005), Card and DiNardo (2000) and Peri and Sparber (2011).
} 
from Denmark and Germany and household survey data from the UK. These data bases enable us to cover the same time period, namely the period from 1993-2009, although further observations are available in Germany and the UK. Albeit some limitations in the comparability of the data still remain, we have tempted to harmonize the definitions and classifications in the individual data sets as much as possible. Therefore we argue that the findings in this paper are more comparable than those from the single-country studies in the literature.

The comparative approach in this paper allows us to provide new insights in two particular areas. First, our estimates of the wage curve allow us to assess whether wage rigidities differ across countries, and, therefore whether immigration has differential wage effects. Although we cannot trace the direct effect of particular labour market institutions on the extent of this wage rigidity, this does at least provide some indirect evidence on the role of labour market institutions. Second, our estimates of the labor demand equations allow us to assess the extent to which the elasticites of substitution (particularly between natives and migrants) differ across countries. Applying several robustness checks demonstrate furthermore how sensitive these estimates are across countries.

The remainder of the paper is organized as follows. Section 2 outlines our theoretical framework. Section 3 briefly describes the data we use. ${ }^{5}$ Section 4 presents the empirical model, the identification strategy and the estimation results for the elasticities of the wage-setting curves and the parameters of the production function. Section 5 simulates the employment and wage impact of immigration in Denmark, Germany and the UK. Finally, Section 6 concludes.

\section{Theoretical framework}

\subsection{Wage-setting theories}

Building on Boeri and Brücker (2005), Brücker and Jahn (2011) and Levine (1999) we apply a wage-setting framework to analyze the wage and employment effects of immigration. Our model replaces the conventional labor supply curve with a wage-setting function. This wage-setting function relies on the simple assumption that wages decline with the unemployment rate, albeit imperfectly. This relationship is empirically widely supported, both at the macro level (e.g. Layard and Nickell, 1986; Layard et al., 2005) and at the regional level (Blanchflower and Oswald 1994; 2005). Theoretically, the assumption of a wage-setting function can be derived from right-to-manage models of collective bargaining (Nickell and Andrews, 1983) and efficiency wage theories derived from turnover cost (Salop, 1979) or shirking (Shapiro and Stiglitz, 1984) models. These models have in common

\footnotetext{
${ }^{5} \mathrm{~A}$ detailed description is provided separately in Appendix B.
} 
the idea that the slope of the wage-setting curve depends on both the mark-up of the wage over the outside option of workers, and on the value of the outside option.

We do not present an explicit collective bargaining or efficiency wage model here, since different types of models may be relevant in our context. Instead, we think of the elasticity of the wage-setting curve as the composite effect of wage-setting mechanisms and other labor market institutions which affect the elasticity of the wage with respect to labor supply changes. We expect that the slope of the wage-setting curve will vary across the three countries in our analysis for a number of reasons.

First, the three countries are characterized by different types of collective bargaining institutions as well as different levels of union density and union coverage. Collective bargaining is heavily concentrated in Denmark, where union density and the coverage of collective agreements is also very high. Collective wage agreements play thus a major role in the determination of wages and the bargaining power of trade unions can be considered as relatively high, suggesting that the wage mark-up is also relatively high. Germany is an intermediate case. Albeit wage bargaining is centralized as well, the union density is low and the coverage of collective contracts have an intermediate level. Finally, the UK is a classical example for decentralized bargaining, where union density is intermediate, but the coverage of collective wage agreements is low. Other wage-setting mechanisms such as efficiency wages or shirking models may be more relevant here.

Second, Germany has a relatively high level of employment protection, compared to the UK and Denmark. Insider-outsider models of collective bargaining (Lindbeck and Snower, 1987, 2001) would therefore predict that the slope of the wage-setting curve is flatter in Germany compared to the UK and Denmark.

Third, transfers to unemployed households are high in Denmark, significantly lower in Germany and lowest in the UK. Both collective bargaining and efficiency wage models predict that this would result, ceteris paribus, in a flatter wage-setting curve in Denmark and Germany compared to the UK.

Fourth, high and progressive taxes may affect the responsiveness of wages for different groups of workers in different ways. Lockwood et al. (2000) find evidence that progressive taxes increase wages for high and medium skilled workers, while wages of less skilled workers remain unaffected. Consequently, it is reasonable to expect that the wage responsiveness to labor supply shocks declines with the skill level of workers in countries with very progressive tax systems such as Denmark.

Fifth, product markets are much more regulated in Germany compared to the UK and Denmark. This would reduce the scope for collective bargaining in the latter countries and, hence, increase the responsiveness of wages to changes in the unemployment rate. However, the high exposure to international competition, particularly in the manufacturing sector in Germany, might reduce the potential impact of product market regulation in that country. 
Thus, the slope of the wage-setting curve is likely to vary between the three countries considered in our study as the complexity of the institutional differences allows no unambiguous predictions. It remains therefore an empirical question whether and to what extent the elasticity of the wage-setting curves will differ.

Finally, following a suggestion by Card (1995), we do not assume that the slope of the wage-setting curve is uniform for all types of workers. The slope of the wage-setting curve is likely to vary with the bargaining power and the human capital characteristics of workers. We therefore allow the elasticity of the wage-setting curve to differ by skill levels in our empirical analysis.

\subsection{A wage-setting model of migration}

Consider an economy where output is produced with different types of labor and capital. Let $\bar{N}_{\ell}$ be the pre-migration labor force in each cell of the labor market, where the subscript $\ell=1, \ldots, n$ denotes the type of labor. The post-migration labor force is then given by

$$
N_{\ell}=\bar{N}_{\ell}+\gamma_{\ell} M, \quad \sum_{\ell=1}^{n} \gamma_{\ell}=1,
$$

where $M$ is the total stock of migrants $\gamma_{\ell}$ is the share of workers of type $\ell$ in the total immigrant inflow.

Firms produce varieties of a differentiated good under monopolistic competition. Production involves some fixed setup costs, but thereafter each firm produces output with constant returns to scale. Hence, production of a representative firm $i$ is given by

$$
Y^{i}=F\left(\mathbf{L}^{i}, K^{i}\right)
$$

where $Y^{i}$ denotes a variety of the output good, $\mathbf{L}^{i}$ the vector of labor inputs, $K^{i}$ is physical capital. Firms do not necessarily employ the entire labor force, i.e. $L_{\ell} \leq N_{\ell}$. The production technology $F(\cdot)$ is increasing, concave, twice continuously differentiable in all inputs and homogeneous of degree one.

Wages and the demand for labor are determined sequentially. In the first stage wages are determined, and in the second stage, given the agreed wages, firms set prices and hire workers up to a level where profits are maximized. Suppose that each firm faces a constant elasticity of demand $\eta>1$. Profit maximization implies that the wage rate equals

$$
w_{\ell}^{i}=P^{i} Y_{L_{\ell}}^{i} \quad \forall \ell
$$

where $P^{i}$ is the product price of variety $i$ of the output good, and $Y_{L_{\ell}}^{i}$ is the marginal product of labor of type $\ell{ }^{6}$

\footnotetext{
${ }^{6}$ One could consider a price mark-up assuming an imperfect competition framework in addition. Since
} 
Assuming that firms are identical, we can move to the level of the aggregate economy by writing $w_{\ell}^{i}=w_{\ell}, Y_{L_{\ell}}^{i}=Y_{L_{\ell}}$, and $P^{i}=P=1$, where we have normalized the price level to one. The real wage is then given by

$$
w_{\ell}=Y_{L_{\ell}}, \quad \forall \ell
$$

In the first stage of the decision process, firms and employees set wages as a function of unemployment, which enables us to write the aggregate wage-setting equation as

$$
w_{\ell}=f_{\ell}\left(u_{\ell}\right), \quad f_{\ell}^{\prime}<0, \quad \forall \ell,
$$

where $f_{\ell}$ is a function that captures the response of the wage to the unemployment rate $u_{\ell}=1-L_{\ell} / N_{\ell}$. The rationale behind equation (4) is that a higher unemployment rate weakens the outside options of workers and, hence, reduces their wages, as outlined in Section 2.1.

The wage-setting relation in equation (4) and the relationship between the real wage and marginal product of labor in equation (3) allow us to solve for the employment response to a change in foreign labor supply. This requires solving a system of equations which is determined by the wage-setting curves and the production function for each type of labor. This system has to satisfy, in each cell of the labor market, the implicit function

$$
\Omega_{\ell}(\mathbf{L}, M) \equiv Y_{L_{\ell}}(\mathbf{L}, K(\mathbf{N}(M)))-f_{\ell}\left(u_{\ell}\left(L_{\ell}, N_{\ell}(M)\right)\right)=0, \quad \forall \ell .
$$

Note that equation (5) implies that the capital stock may adjust to labor supply shocks, i.e., that $\partial K / \partial \mathbf{N} \geq 0$. Differentiating this system implicitly with respect to a marginal labor supply shock through immigration yields, for the change in employment

$$
\frac{d \mathbf{L}}{d M}=\left(\frac{\partial \mathbf{Y}_{\mathbf{L}}}{\partial \mathbf{L}}-\frac{\partial \mathbf{f}}{\partial \mathbf{u}} \frac{\partial \mathbf{u}}{\partial \mathbf{L}}\right)^{-1} \times\left(\frac{\partial \mathbf{f}}{\partial \mathbf{u}} \frac{\partial \mathbf{u}}{\partial \mathbf{N}} \frac{d \mathbf{N}}{d M}-\frac{\partial \mathbf{Y}_{\mathbf{L}}}{\partial K} \frac{\partial K}{\partial \mathbf{N}} \frac{d \mathbf{N}}{d M}\right)
$$

where $\mathbf{Y}_{\mathbf{L}}$ denotes a vector of the marginal products of labor in each cell as in equation (3), $\mathbf{f}$ the vector of wage-setting functions that determines the wage response to the unemployment rate as outlined in equation (4), and $\mathbf{u}$ is the vector of unemployment rates.

Having solved for the equilibrium employment response, it is straightforward to use the relation in equation (3) to derive the wage effects of migration:

$$
\frac{d \mathbf{w}}{d M}=\frac{\partial \mathbf{Y}_{\mathbf{L}}}{\partial \mathbf{L}} \frac{d \mathbf{L}}{d M}+\frac{\partial \mathbf{Y}_{\mathbf{L}}}{\partial K} \frac{\partial K}{\partial \mathbf{N}} \frac{d \mathbf{N}}{d M} .
$$

It is clear that the employment response to migration in equation (6) decreases with (i) the absolute value of the elasticity of the wage with respect to the unemployment rate, (ii) the adjustment of the capital stock to the labor supply shock and (iii) the elasticity between

this does not add anything to the results of our analysis, we rely on the most parsimonious framework for the sake of convenience here. 
the marginal product of labor and the capital stock. The response declines with the absolute value of the elasticity between the marginal product of labor and employment. ${ }^{7}$ In contrast, wages decline with the absolute elasticity of the wage-setting curve.

This simple model establishes the general framework for our analysis. In the empirical specification of the model we distinguish labor by education, work experience and national origin. The wage-setting curves are estimated separately for the different skill groups in the labor force, while the labor demand functions for the different types of labor are estimated by using a nested CES production function.

\section{Description of the data}

We use three micro data sets in our empirical analysis: the Integrated Database for Labor Market Research (IDA) in Denmark, the Integrated Employment Biographies (IEB) in Germany and the Quarterly Labour Force Survey (LFS) for the UK. The IDA and the IEB are administrative data derived from social security records, while the LFS is based on quarterly household surveys.

The IDA is compiled from a variety of sources such as the population register, the labor force and unemployment registers and administrative tax data (Statistics Denmark, 2007). It covers the entire population including all employed and unemployed persons. Immigrants can be identified both by their country of birth and citizenship.

The IEB is a $5 \%$ random sample of all employees registered with the social security system, and of all unemployment benefit recipients in Germany. Self-employed individuals and civil servants who are not obliged to pay social security contributions (Beamte) are not covered in the data set. As with the IDA, the IEB is compiled from a variety of administrative data sources which comprise, inter alia information on employment histories provided by the German pension system and on unemployed benefit recipients provided by the Federal Employment Services (Dorner et al., 2010). Due to the German jus sanguis tradition, the data set identifies foreigners only by citizenship.

Administrative data on earnings in the UK are not available to researchers. The largest survey which contains information on migration status is the UK Labour Force Survey, ${ }^{8}$ a quarterly random sample of 60,000 households (Office for National Statistics, 2011). Each quarter of the LFS sample is made up of five waves, each of approximately 12,000 households. Each wave is interviewed in five successive quarters. As a result, there is an $80 \%$ overlap in the samples for successive quarters. The UK LFS contains information on wages, qualification, occupational status, unemployment, the country of birth of foreigners

\footnotetext{
${ }^{7}$ Note that the derivative of the unemployment rate with respect to employment is negative, while it is positive with respect to the labor force.

${ }^{8}$ The Annual Survey of Hours and Earnings (ASHE) provides a larger sample size, but no information on nationality or country of birth.
} 
as well as information on citizenship. Wage information is not available before 1993, so we use the 1993-2010 period in our analysis.

Since the purpose of our study is to analyze the effects of exogenous changes in the immigrant workforce, the measure of the immigrant labour supply should be as free as possible from measurement error that would otherwise attenuate our estimates, a problem also highlighted recently by Aydemir and Borjas (2011) and Manacorda et al. (2012). Attenuation bias is ruled out by definition in the Danish data, where we can use the entire population. It is also no concern in Germany, where both the sample size and the sampling methodology rules out that immigrants - in the definition we apply here - are under-represented. Although smaller than the German and Danish samples, the LFS is the largest UK data source available to researchers which provides information on wages and employment spells for natives and immigrants. ${ }^{9}$ Because of its smaller size, there may be concerns that UK estimates suffer from attenuation bias as a result of measurement error in the proportion of foreigners in a labour market cell. However, our estimate of the size of the likely bias (see Aydemir and Borjas, Eq. 8) is under 2\%, largely because the cell sizes we use are still relatively large.

The sample periods are largely harmonized across countries. In our estimates of the wage-setting curves we use the 1993-2009 period in all three countries, since the choice of the time period might be particularly relevant here due to the financial crisis. For the elasticities of substitution we chose the 1993-2010 period for Germany and the UK, while we used the 1993-2009 period for Denmark. Observations for 2010 are not yet available for Denmark. We decided to chose the maximum period in case of Germany and the UK here, since the results turned out to be more robust if the period is longer, albeit differences are altogether modest.

We harmonize the definitions and categories in the three data sets as far as possible, although some differences remain. The most important difference is that the Danish IDA and the UK LFS allow us to identify immigrants by country of birth, while the German IEB distinguishes natives and foreigners by citizenship. We therefore use further information from the IEB to get as close as possible to the internationally comparable concept of foreign-born. First, we classify all individuals as foreigners who are reported as foreign citizens in their first available spell. This prevents naturalizations from being recorded as a declining foreigner share in our sample. Second, we define ethnic Germans so-called Spätaussiedler - as foreigners. In the IEB ethnic Germans are coded as German citizens. However, we are able to identify this group by their participation in active labor market programs especially designed for ethnic Germans (such as language courses and other integration programs). This enables us to identify the overwhelming share of this non-trivial immigrant influx of about 3.1 million persons since the fall of the Iron Curtain. The main remaining difference between the measure of migrants in the German data and

\footnotetext{
${ }^{9}$ It has been used recently to estimate wage effects of immigration in the UK by Dustmann et al. (2008) and Manacorda et al. (2012).
} 
the foreign-born measure is that we are not able to exclude second- and third-generation immigrants who did not acquire German citizenship before entering the labor force. ${ }^{10}$

We classify native and foreign workers by education and work experience. In our view it is most suitable to distinguish three education groups in European labor markets: low skilled workers, skilled workers and workers with a university degree. Since educational systems differ across our three countries, we have used country-specific classifications. Statistics Denmark provides information on the highest attained education. Low skilled workers are defined as those who left school without any further education, medium skilled workers have a vocational training degree and high skilled workers hold at least a bachelor degree. In Germany we classify workers by educational degrees as well: low skilled workers have no vocational degree, medium skilled workers a vocational training degree and high skilled workers a university degree. In the UK, low skilled workers are defined as those who left school at 17 or younger, medium skilled workers are those who left school between 18 and 20, and high-skilled individuals left education at 21 years or older. ${ }^{11}$

We distinguish four groups of work experience: 5 years or less, 6 to 10 years, 11 to 19 years, 21 years or more. This ensures that we have sufficient observations in each cell of the labor market in all three data sets.

As robustness checks, we used also alternative measures for education and experience: First, we used occupation instead of education for controlling for the potential skill-downgrading of immigrants. Second, assuming that work experience acquired abroad is downgraded after arrival as well, but converges over time, we counted as an alternative experience measure for the first ten years after arrival only the experience acquired in the host country, while after ten years the total work experience is considered. Finally, we combined both alternative classifications. Details are discussed in section 4.2.

We consider male and female workers throughout our analysis. Since the German data set does not contain information on hourly wages and hourly wages for part-time workers with few hours are known to be of bad quality, we consider full-time employees in all three data sets. Unemployed individuals are identified in the Danish and the German data set as recipients of unemployment benefits and allowances, while the UK LFS relies on the self-reported ILO definition of unemployment. Wages are deflated by the CPI.

In the wage-setting equations we consider as macroeconomic controls the real GDP growth rate, annual inflation of all prices (the GDP deflator) and an export propensity index (ratio of exports to GDP). The first two variables have been taken from the World Development Indicator database of the World Bank (2013), the latter one from the OECD (2013). As instrumental variables we use an export demand index, a trade-weighted index

\footnotetext{
${ }^{10}$ As a robustness check, we have also produced data sets for Denmark and the UK which identify foreigners by citizenship. The results do not differ greatly, and we therefore restrict the analysis presented here to the more common concept of foreign-born.

${ }^{11}$ These three groups capture the three basic levels of educational qualification in the UK, namely GCSE, A-level and university degree.
} 
of the GDP of the trading partners in the OECD, which has been calculated based on data provided by the OECD (2013), and an industry-mix variable, a shift-share index of employment growth, which has been derived from our micro data. For the estimates of the elasticities of substitution we use in Denmark the average age of the youngest child as an instrument, an information which is provided by the IDA data set. In Germany we consider the average number of children of an age between eight and sixteen, an information which has been collected from the German Socio-economic Panel (SOEP). Finally, in the UK we use the median household income of unemployed individuals from the British Household Panel Survey (BHPS). In addition we use for the estimates of the elasticities of substitution between natives and immigrants as instruments an government ideology index, which is provided by Bjørnskov (2008), and the minimum wage in the UK (Low Pay Commission).

A detailed description of the three data sets and the definitions of the variables are presented in Appendix B; Table 9 contains also a list of all control and instrumental variables.

Table 2 presents some descriptive information of the data. The skill structure of employment reveals some interesting differences between the three countries. In Denmark, the immigrant workforce is concentrated in both the low and high education groups relative to natives. In Germany, immigrants are over-represented in the group with low education, but under-represented in the medium and high skilled groups. Finally, in the UK, immigrant workers are much better qualified as natives and display disproportional high shares in the high and medium skill groups.

In all three countries we observe that immigrants are disproportionately affected by unemployment. In Denmark the unemployment rates of immigrants in 2009 exceed those of natives by a factor between 2.2 and 2.3 depending on the education group; in Germany by a factor of 1.6 and 2.2 , in the groups of medium and high skilled workers, respectively, while unemployment of immigrants is below that of natives in the less skilled group. In the UK, differences in unemployment rates between immigrants and natives vary by a factor of between 1.4 and 1.7. 
Table 2: Employment, unemployment, and wages by education, 2009

\begin{tabular}{|c|c|c|c|c|c|c|c|c|c|}
\hline & \multicolumn{3}{|c|}{$\begin{array}{l}\text { Education group }{ }^{\mathrm{a}} \text { in } \% \\
\text { of total employment }\end{array}$} & \multicolumn{3}{|c|}{$\begin{array}{l}\text { Unemployment rate }{ }^{\mathrm{b}} \text { by } \\
\text { education group in } \%\end{array}$} & \multicolumn{3}{|c|}{$\begin{array}{c}\text { Wages }^{\mathrm{c}} \text { by } \\
\text { education group }\end{array}$} \\
\hline & Low & Med & High & Low & Med & High & Low & Med & High \\
\hline & \multicolumn{9}{|c|}{ Denmark } \\
\hline Natives & 24.95 & 63.64 & 11.41 & 7.25 & 4.41 & 3.79 & 150.93 & 178.68 & 228.65 \\
\hline Immigrants & 33.87 & 51.87 & 14.26 & 15.83 & $\begin{array}{l}10.21 \\
\text { Germ }\end{array}$ & $\begin{array}{l}8.41 \\
\mathbf{y}\end{array}$ & 141.92 & 162.65 & 210.73 \\
\hline Natives & 5.68 & 78.44 & 15.88 & 43.05 & 13.81 & 5.18 & 73.35 & 85.73 & 145.26 \\
\hline Immigrants & 26.42 & 62.95 & 10.62 & 36.48 & $\begin{array}{r}22.00 \\
\text { UK }\end{array}$ & 11.51 & 65.07 & 77.36 & 132.57 \\
\hline Natives & 55.30 & 20.79 & 23.91 & 12.40 & 8.50 & 4.82 & 10.00 & 11.88 & 15.73 \\
\hline Immigrants & 23.02 & 29.33 & 47.65 & 18.27 & 11.57 & 8.29 & 9.15 & 9.79 & 14.26 \\
\hline
\end{tabular}

${ }^{a}$ In Denmark, low education is defined as no vocational training, medium education as vocational training, and high education as a bachelor or above. In Germany, low education is defined as no vocational training, medium education as vocational training, and high education by a university degree. In the UK, education levels are defined by age left school: low $<18$, medium: $18-21$, high: $\geq 21$.

$\mathrm{b}$ The unemployment rate is defined here as the ratio of all unemployed persons to the sum of full-time employed and all unemployed persons. Note that part-time workers who are not covered by our definition of employed workers are disproportionately represented in the low skilled segment of the labor market.

${ }^{c}$ In Denmark, wages are defined as hourly wages in Danish Crowns (2000 constant prices), in Germany as daily wages in Euros (2005 constant prices), and in UK as hourly wages in British Pounds (2005 constant prices).

Not surprisingly, wages of immigrant workers are lower than those of native workers. In Denmark, the wages of low, medium and high-skill immigrants are, respectively, $6 \%, 9 \%$ and $8 \%$ below those of equivalent natives in 2009. In Germany, wage levels of low, medium and high-skill immigrants are, respectively, $11 \%, 10 \%$ and $9 \%$ below those of equivalent natives at the same time. Finally, wage differentials between native and immigrant workers are $8 \%$ for low, $18 \%$ for medium, and 9\% for high skilled employees in the UK in 2009.

\section{Empirical specification and estimation}

\subsection{Wage-setting equations}

The first step of our empirical analysis is the estimation of the wage-setting equations. As outlined in Section 2, we expect the wage-setting curves to vary across different groups in the labor market. For the estimation we use the variance in the data across education $(q=1,2,3)$ and experience groups $(j=1,2,3,4)$ as defined in Section 3 , but impose the restriction that the slope parameter of the wage-setting curve is uniform across experience groups. This increases the efficiency of estimation without imposing a too demanding restriction on the parameter of interest.

More specifically, we estimate the following wage-setting equation separately for each 
country: ${ }^{12}$

$$
\ln w_{q j t}=\beta_{q} \ln u_{q j t}+\lambda_{q j} \tau_{q j t}+\eta^{\prime} \mathbf{x}_{t}+\epsilon_{q j t},
$$

where $u_{q j t}$ denotes the unemployment rate in education-experience cell $(q, j), \tau_{q j t}$ is an education-experience specific deterministic time trend, and $\mathbf{x}_{t}$ is a vector of control variables. As controls we use in all three countries the real GDP growth rate, the annual inflation of all prices measured by the GDP deflator, and an export propensity indicator which is defined as the ratio of export to GDP and captures thus external demand in the goods markets. ${ }^{13}$ We thus capture both domestic and external shocks in output, demand and prices. The error term $\epsilon_{q j t}$ is specified as a one-way error component model with a fixed effect for each education-experience cell $(q, j)$.

The specification of equation (8) is similar to that used in the wage-setting and wage curve literature, but it differs in that it allows the elasticity between wages and the unemployment rate to vary across education groups. This enables us to capture different degrees of wage flexibility in different skill segments of the labor market.

A simultaneity problem arises in the estimation of (8) if an unobserved shock to the wage will via the demand curve raise unemployment, and this will bias the estimate of the (assumed negative) coefficient towards zero. Using lags as IVs does not help here, because an unobserved persistent wage shock occurred in the past, raising lagged wages and unemployment, as well as current ones. Moreover, unemployment might itself be a affected by the wage rate. Beyond controlling for other factors affecting wages, we have therefore to find an exogenous IV for the unemployment rate without directly affecting the wage equation. Suitable IVs considered in the literature are trade-weighted measures of foreign economic activity and sector-specific demand indices (Blanchard and Katz, 1992; Carlsson et al., 2008, 2006; Forslund et al., 2008).

We apply two instrumental variables here. The first one - the export demand index is defined as the log GDP of the trading partners in the OECD weighted by their average trade shares during the sampling period (see Annex B.3 for the calculation of the variable). This variable should capture exogenous demand shifts in open economies. It is a valid instrument if wages and prices are rigid in the short-run - which is supported by ample empirical evidence - such that an external demand shock should affect (un-)employment in the first place and wages only in the second place via a change in the (un-)employment rate. This is what standard open-economy macroeconomic models predict (Baldwin and Wyplosz, 2012; Krugman et al., 2011), but also more sophisticated models which consider search-frictions (Carlsson et al., 2008).

Our second IV is borrowed from the regional wage curve literature (e.g. Bartik, 1991; Blanchard and Katz, 1992; Blanchflower and Oswald, 1994). A popular instrument for the (un-)employment rate is a shift and share measure of local industrial mix that predicts

\footnotetext{
${ }^{12}$ Country subscripts are omitted to clarify the notation

${ }^{13}$ see Appendix B for a definition of variables
} 
the local employment growth rate under the assumption that each of the state's industries had the same employment growth rate as the national average employment growth rate for that sector there (Bartik, 1991, 1993; Blanchard and Katz, 1992; Bound and Holczer, 2000). Analogously we constructed an industry mix variable which measures how much of the deviation in employment growth in each education-experience cell from the average employment growth can be explained by the concentration of workers in the respective cell in fast or slow growing industries (see Annex B.3 for the calculation of the variable). This variable captures how much of the change in employment can be attributed to a shift in sectoral structure, triggered by exogenous factors such as technological change. It is a valid instrument if national industry growth rates are uncorrelated with labor supply shocks in the education-experience cell. This in turn will be true if sectoral employment is not too concentrated in any education-experience cell, a condition that appears satisfied in the data set used. Because we use the deviation of this variable from the national growth rate of employment, this deviation will be a good instrument if the education-experience cells differ sufficiently in their sectoral employment composition. This condition also appears to be satisfied.

Throughout our regressions we follow Borjas et al. (2012) in weighting the cells by the inverse of the variance of the log mean wage which controls inter alia for sampling error in the wages ${ }^{14}$ Only as robustness checks, we also apply weights which refer to the cell size. In our regressions, we refer to the 1993-2009 sample period, i.e. we consider exactly the same period for all three countries, although some further observations are available for Germany and the UK. ${ }^{15}$

\footnotetext{
${ }^{14}$ More specifically, we use the following weight in the wage regressions: $\omega_{q j t}=\frac{1}{\operatorname{var}\left[\ln \bar{w}_{q j t}\right]}=$ $\frac{L_{q j t}\left(\bar{w}_{q j t}\right)^{2}}{s_{q j t}^{F}\left(\sigma_{q j t}^{F}\right)^{2}+s_{q j t}^{H}\left(\sigma_{q j t}^{H}\right)^{2}}$, where $L_{q j t}$ denotes the number of employed workers in education group $q$ and experience group $j, \bar{w}_{q j t}$ the mean wage, $s_{q j t}^{F}$ the share of immigrants in the labor force of education group $q$ and experience group $j, s_{q j t}^{H}$ the respective share of natives, and $\left(\sigma_{q j t}^{F}\right)^{2}$ and $\left(\sigma_{q j t}^{H}\right)^{2}$ the variance of the wages in the respective education-experience cell of immigrants and natives, respectively.

${ }^{15}$ Robustness checks suggest that prolonging the sampling period increases somewhat the regression coefficients, but does not alter qualitatively our results.
} 
Table 3: Estimates of the wage-setting curve

\begin{tabular}{|c|c|c|c|c|}
\hline Education level & Coeff. & $\mathrm{SE}$ & $\mathrm{R}^{2}$ & Obs. \\
\hline & \multicolumn{4}{|c|}{ IV } \\
\hline & \multicolumn{4}{|c|}{ Denmark $^{a}$} \\
\hline All & $-0.115^{* * *}$ & $(0.028)$ & 0.98 & 192 \\
\hline Low & $-0.121^{* * *}$ & $(0.035)$ & 0.98 & 64 \\
\hline Medium & $-0.093^{* * *}$ & $(0.017)$ & 0.95 & 64 \\
\hline \multirow[t]{2}{*}{ High } & $-0.065^{* * *}$ & $(0.021)$ & 0.98 & 64 \\
\hline & \multicolumn{4}{|c|}{ Germany $^{\mathrm{b}}$} \\
\hline All & $-0.116^{* * *}$ & $(0.031)$ & 0.99 & 192 \\
\hline Low & $-0.047^{* *}$ & $(0.021)$ & 0.99 & 64 \\
\hline Medium & $-0.116^{* * *}$ & $(0.038)$ & 0.98 & 64 \\
\hline \multirow[t]{2}{*}{ High } & $-0.167^{* *}$ & $(0.078)$ & 0.96 & 64 \\
\hline & \multicolumn{4}{|c|}{$\mathbf{U K}^{\mathrm{c}}$} \\
\hline All & $-0.133^{* * *}$ & $(0.030)$ & 0.99 & 192 \\
\hline Low & $-0.072^{* *}$ & $(0.030)$ & 0.99 & 64 \\
\hline Medium & $-0.143^{* * *}$ & $(0.035)$ & 0.99 & 64 \\
\hline \multirow[t]{3}{*}{ High } & $-0.249^{* * *}$ & $(0.083)$ & 0.97 & 64 \\
\hline & \multicolumn{4}{|c|}{ OLS } \\
\hline & \multicolumn{4}{|c|}{ Denmark } \\
\hline All & $-0.040^{* * *}$ & $(0.005)$ & 0.99 & 192 \\
\hline Low & $-0.039^{* * *}$ & $(0.010)$ & 0.99 & 64 \\
\hline Medium & $-0.046^{* * *}$ & $(0.007)$ & 0.98 & 64 \\
\hline \multirow[t]{2}{*}{ High } & $-0.023^{* * *}$ & $(0.006)$ & 0.99 & 64 \\
\hline & \multicolumn{4}{|c|}{ Germany } \\
\hline All & $-0.023^{* *}$ & $(0.009)$ & 0.99 & 192 \\
\hline Low & $-0.037^{* * *}$ & $(0.013)$ & 0.99 & 64 \\
\hline Medium & -0.016 & $(0.012)$ & 0.99 & 64 \\
\hline \multirow[t]{2}{*}{ High } & $-0.059^{* * *}$ & $(0.017)$ & 0.97 & 64 \\
\hline & \multicolumn{4}{|c|}{ UK } \\
\hline All & $-0.041^{* * *}$ & $(0.014)$ & 0.99 & 192 \\
\hline Low & -0.024 & $(0.023)$ & 0.99 & 64 \\
\hline Medium & $-0.078^{* * *}$ & $(0.022)$ & 0.99 & 64 \\
\hline High & $-0.047^{*}$ & $(0.027)$ & 0.98 & 64 \\
\hline
\end{tabular}

Heteroskedasticity-robust standard errors in parentheses.- ${ }^{* * *}$, **, * denote the 1\%-, 5\%-, 10\%-significance levels, respectively.Dependent variable is the log wage in each education-experience class.- Macroeconomic controls are real GDP growth rate, overall inflation, and the export propensity index, as well as education specific deterministic time trends and education-experience dummies. All estimations are weighted (see main text).

IVs are the lagged log export demand variable and the lagged industry-mix variable.

a The $p$-value of the Hansen- $J$-statistic is 0.93 , the KleibergenPaap $F$-statistic for weak instruments is 6.65 and the Kleibergen-Paap rk $L M$ test statistic for underidentification is 21.11 in the pooled Danish regression.

$\mathrm{b}$ The $p$-value of the Hansen- $J$-statistic is 0.59 , the KleibergenPaap $F$-statistic for weak instruments is 14.61 and the Kleibergen-Paap rk $L M$ test statistic for underidentification is 24.13 in the pooled German regression.

c The $p$-value of the Hansen- $J$-statistic is 0.74 , the KleibergenPaap $F$-statistic for weak instruments is 36.91 and the Kleibergen-Paap rk $L M$ test statistic for underidentification is 24.24 in the pooled UK regression. 
The first panel in Table 3 presents the 2sls regression results for Denmark, Germany and the UK. All regressions have the expected negative sign and the coefficient on the unemployment rate appears significant or highly significant in all segments of labor market in all countries. The pooled regression results (across all three skill groups combined) indicate that the elasticity of the wage-setting curve is relatively high in the United Kingdom $(-0.133)$ and lower in Germany $(-0.116)$ and Denmark $(-0.115)$. The pooled results confirm by and large the estimates in the regional wage curve literature, which usually find an elasticity of about -0.1 (Bell et al., 2002; Blanchflower and Oswald, 1994; 2005).

The absolute value of the elasticity of the wage-setting curve is thus largest in the UK, i.e. in that country where wages are set at the firm level, where union density is low, where employment protection is weak and the replacement rate is low compared to the other countries. This confirms our a priori expectations. The differences to Germany and Denmark are however not that large, although particularly Denmark is characterized by a higher coverage of collective wage contracts and union density.

The estimation results by skill groups reveal interesting insights as well. In Germany and the UK, the absolute value of the elasticity of the wage-setting curve is monotonically increasing with the skill level, suggesting that wage-flexibility is highest in the labor market segment of workers with a college or university degree. This might reflect the fact that the union density is lower there and collective wage contracts are less effective in this segment. In contrast, we find that the elasticity of the wage-setting curve is lowest in the high-skilled segment in Denmark, while we find the largest elasticity in the low skilled segment there. This can be explained by two institutional features. First, in contrast to Germany and the UK, union density is not declining and collective wage agreements are still effective in the high-skilled segment of the Danish labor market. Second, high and progressives taxes result in higher wage requests and a lower wage responsiveness for high and medium skilled workers in Denmark (Lockwood et al., 2000). IT is also worthwhile to note that the overall differences in the elasticities e.g. between the UK and Denmark are larger when we consider the results from the different skill-groups compared to the aggregate estimates.

Our test results support in general our instrumentation strategy. The Hansen- $J$ statistics do not reject the null of no overidentification in all three countries. The Kleibergen Paap rk $L M$-statistics rejects the null of underidentification at the $1 \%$ level in all three countries. In Germany and Denmark high values of the Kleibergen Pap rK F-test statistics reject the hypothesis that the instruments are weak and suggest that the estimation bias is small. However, the rather low level of the $F$-test statistics suggest that our IVs may be weak in Denmark. Nevertheless, since the size of the coefficients look reasonable and since they appear as highly significant also in the OLS regressions, we think that the potential estimation bias is not too severe even in this case.

The second panel in Table 3 reports the pooled OLS estimation results The OLS 
regressions deliver in all regressions the correct signs. Moreover, the aggregate regressions appear highly significant in all three countries, and the regressions by education groups also in Denmark and - with one exception - Germany. In the UK, one coefficient is weakly significant and another one insignificant. Altogether we interpret the results from the OLS regressions as reassuring, although we believe that the OLS estimates are downward biased.

\subsection{Labor demand equations}

For the estimation of the labor demand equation, we have to impose some structure on the aggregate production function of the economy. In the same way as Borjas (2003), Brücker and Jahn (2011) and Ottaviano and Peri (2012) we follow Card and Lemieux (2001) and use a nested CES production function. More specifically, we employ a four-level production function which groups the workforce into $q=1, \ldots, 3$ education groups, $j=1, \ldots, 4$ work experience groups, and $k=1,2$ (native, foreign) nationality groups. Although the nested CES function imposes some restrictions on the elasticities of substitution, it has the advantage that it is parsimonious in its parameters.

Suppose that aggregate production in equation (2) can be represented by a standard Cobb-Douglas production function:

$$
Y_{t}=A_{t} L_{t}^{\alpha} K_{t}^{1-\alpha}
$$

where $Y_{t}$ denotes aggregate output, $A_{t}$ is an exogenous parameter which captures total factor productivity, $L_{t}$ is aggregate labor input, $K_{t}$ is physical capital, $\alpha$ is the production elasticity of labor, and $t$ is a time index.

The aggregate labor input, $L_{t}$, can be built up from $L_{q j k t}$, the number of workers of education $q$, experience $j$ and national origin $k$ in the following way:

$$
\begin{aligned}
L_{q j t} & =\left[\sum_{k=1}^{2} \theta_{q j k} L_{q j k t}^{(\sigma-1) / \sigma}\right]^{\sigma /(\sigma-1)} & \sum_{k=1}^{2} \theta_{q j k}=1, \\
L_{q t} & =\left[\sum_{j=1}^{4} \theta_{q j} L_{q j t}^{(\rho-1) / \rho}\right]^{\rho /(\rho-1)} & \sum_{j=1}^{4} \theta_{q j}=1, \\
L_{t} & =\left[\sum_{q=1}^{3} \theta_{q t} L_{q t}^{(\delta-1) / \delta}\right]^{\delta /(\delta-1)} & \sum_{q=1}^{3} \theta_{q t}=1 .
\end{aligned}
$$

Thus, $L_{q t}$ is a labor composite that aggregates all workers with education $q$ and $L_{q j t}$ aggregates native and migrant workers of education $q$ and experience $j$. The technology parameters $\theta_{q t}, \theta_{q j}$, and $\theta_{q j k}$ determine the productivity levels of the respective factor. We allow the productivity parameter $\theta_{q t}$ to vary over time since skill-biased technological 
progress might affect the productivity of various types of labor in different ways (Katz and Murphy, 1992). The other production parameters are assumed to be constant over time.

Finally, $\delta>0, \rho>0$, and $\sigma>0$ are constant parameters measuring the elasticity of substitution between labor of different educational levels, between workers with similar education but different work experience, and between native and migrant workers with similar education and experience levels. Our a priori expectation is that workers within each experience group are closer substitutes than those across skill groups, which implies that $\rho>\delta$.

Based on equation (3) we can write the real wage rate as the marginal product of labor divided by the mark-up factor. Using the nested CES production function we thus write the $\log$ wage of a worker with skill $q$, experience $j$ and national origin $k$ as

$$
\begin{aligned}
\ln w_{q j k t} & =\ln \left(\nu^{-1} \alpha A_{t}^{1 / \alpha}\right)+\frac{1}{\delta} \ln L_{t}+\ln \theta_{q t}-\left(\frac{1}{\delta}-\frac{1}{\rho}\right) \ln L_{q t} \\
& +\ln \theta_{q j}-\left(\frac{1}{\rho}-\frac{1}{\sigma}\right) \ln L_{q j t}+\ln \theta_{q j k}-\frac{1}{\sigma} \ln L_{q j k t}+\frac{1-\alpha}{\alpha} \ln \kappa_{t},
\end{aligned}
$$

where $\kappa_{t} \equiv K_{t} / Y_{t}$ denotes the capital-output ratio.

From equation (13) we can derive the labor demand functions. Our identification strategy differs from that traditionally used in the literature. As noted, the standard literature applying a production function framework treats labor supply as inelastic and exogenous and assumes that labor markets clear. Consequently, they use employment as the exogenous and wages as the endogenous variable (Card and Lemieux, 2001; Borjas, 2003; Ottaviano and Peri, 2012). In contrast, it follows from our wage-setting framework that labor demand is endogenously determined once wages are fixed. Employment is therefore the dependent variable, and the wage is the independent variable.

Let us start with the identification of the elasticity of substitution between native and foreign workers. Based on equation (13) we can express the relative demand for native and foreign workers with education $q$ and experience $j$ as

$$
\ln \left(L_{q j 1 t} / L_{q j 2 t}\right)=\sigma \ln \left(\theta_{q j 1} / \theta_{q j 2}\right)-\sigma \ln \left(w_{q j 1 t} / w_{q j 2 t}\right)
$$

where the index $k=1,2$ denotes natives and foreigners respectively. We estimate this equation as

$$
\ln \left(L_{q j 1 t} / L_{q j 2 t}\right)=D_{q j}-\sigma \ln \left(w_{q j 1 t} / w_{q j 2 t}\right)+\varepsilon_{q j t},
$$

where $D_{q j}$ denotes a vector of dummy variables for each education-experience cell and $\varepsilon_{q j t}$ a zero-mean disturbance term. Notice that by using the ratio of the wage equations for natives and foreigners, the education and experience levels of the nested production function disappear, such that we do not have to use control variables in estimating the elasticity of substitution between natives and foreigners. 
Following the approach of Ottaviano and Peri (2012) the dummy variables in each education-experience cell capture the log of the relative labor productivity of natives and foreigners times the elasticity of substitution. This implies that the relative productivity of natives and immigrants varies across education and experience groups but is constant over time. ${ }^{16}$

Estimating equation (14) by OLS suffers from simultaneity bias when an unobserved shock to labour demand raises the wage and, thus, biases the estimated coefficient towards zero. A suitable instrumental variable thus has to move the wage without directly affecting labour demands. Those instruments could refer to the reservation wage. Variables which approximate the reservation wage are valid instruments if they affect wages, but not directly labour demand (only via the wage rate).

Although the rationale behind our instruments is the same, we were not able find exactly the same instruments in all three countries which full-fill the exclusion restrictions and are strongly correlated with the wage rate at the same time. This can be traced back to data limitations, but also to institutional differences which affect economic behaviour in different ways in different countries. In Denmark and Germany we have chosen children of employed persons as an instrument for the reservation wage, although the definition differs between the two countries: In Denmark our instrument is the average age of the youngest child, while in Germany it is the average number of children in the age group between eight and sixteen years. ${ }^{17}$ Note that childcare is poor in Germany in this age group, while the government provides comprehensive childcare for all age groups in Denmark. Children turned out to be only weakly correlated with the wage rate in the UK case. For avoiding estimation bias, we decided therefore to use the median household income of the unemployed as an instrument, which again affects the reservation wage and is more strongly correlated with the wage rate than the number or the age of children in the UK case.

For the estimation of the elasticity of substitution we used in addition a government ideology index as an instrumental variable in all three countries. This instrument is calculated as the share of left- and right-wing parties in the government weighted by their seats in parliament (Bjørnskov, 2008). ${ }^{18}$ It captures government policies and legislation that can affect reservation wages through different channels, such as progressive taxation, generosity of welfare benefits, and so on. Note that foreigners' access to welfare benefits is a core issue in the policy debate, which in turn affects relative reservation wages for foreigners and natives. Finally, in the UK we use the annual minimum wage in British Pounds for adult workers as an instrument, which should affect wages of natives and

\footnotetext{
${ }^{16}$ Borjas et al. (2008) suggest also including interaction dummies of the education-experience-specific fixed effects with linear time trends, which would absorb a large part of the identifying variation. However, there is no empirical evidence that the relative labor productivity of foreigners has changed systematically over time at a given level of education and work experience.

${ }^{17}$ The average number of children by age groups is not available in the Danish IDA data set.

${ }^{18}$ We are grateful to Christian Bjørnskov who provided the ideology indices.
} 
foreigners again in different ways.

Table 4: 2SLS-estimates of the elasticity of substitution between natives and foreigners

\begin{tabular}{lccc}
\hline & Denmark $^{\mathrm{a}}$ & Germany $^{\mathrm{b}}$ & UK $^{\mathrm{c}}$ \\
\hline$-\sigma$ & $-16.906^{* * *}$ & $-6.713^{* * *}$ & $-8.891^{* * *}$ \\
& $(2.259)$ & $(0.802)$ & $(1.248)$ \\
\hline Hansen J-statistics (p-value) & 0.52 & 0.20 & 0.76 \\
Kleibergen-Paap F-statistic & 19.67 & 20.59 & 11.02 \\
Kleibergen-Paap LM-statistic & 30.49 & 36.26 & 34.40 \\
$\mathrm{R}^{2}$ & 0.42 & 0.92 & 0.78 \\
Observations & 204 & 214 & 215 \\
\hline
\end{tabular}

Heteroskedasticity-robust standard errors in parentheses. - ***, **, * denote the 1\%-, 5\%-, 10\%-significance levels, respectively. - All estimations include a full set of education-experience controls. All estimations are weighted (see main text).

${ }^{\text {a }}$ IVs are average age of youngest child of employed persons within each educationexperience group, a government ideology index and its lag.

${ }^{\mathrm{b}}$ IVs are ratio of the average number of children of employed persons in an age between 8 and 16 of natives to immigrants within each education-experience group, a government ideology index and its lag.

${ }^{\mathrm{c}}$ IVs are ratio of the median household income of unemployed individuals between natives and immigrants, the annual minimum wage of adult workers in British Pounds, and a government ideology index.

Table 4 presents the 2SLS estimates of equation (14). In all three countries we have the expected signs for the elasticity of substitution. We find that the elasticity of substitution between natives and foreigners is relatively high in Denmark $(-11.1)$, but relatively low in the United Kingdom (-8.9) and Germany (-6.7).

Our estimates are slightly higher than those of Manacorda et al. (2012) for the UK), who estimate an elasticity of -7.8. In Germany, our estimates are quite similar to that estimated by Brücker and Jahn (2011) (-7.0) and Felbermayr et al. (2010) (-7.4), but much lower than the estimates by D'Amuri et al. (2010) (-21.7). ${ }^{19}$ For Denmark, comparable estimates do not exist, to the best of our knowledge.

The finding that natives and immigrants are imperfect substitutes in the labor market has important consequences for the wage and employment effects of immigration. The lower the elasticity of substitution between natives and immigrants the more are the adverse labor market effects of immigration concentrated in the foreigner cells of the labor market. Our findings indicate that foreigners are particularly affected in Germany, while the effects are more dispersed across the native and foreigner cells in the UK and, in particular, Denmark.

Given the high relevance of this elasticity and the ongoing controversies in the literature on its extent, we have carried out several robustness checks which should deliver additional

\footnotetext{
${ }^{19}$ Note that D'Amuri et al. (2010) employ another estimation and instrumentation strategy.
} 
insights on how sensitive estimates of the elasticities of substitution respond to different specifications (see Table 5).

Table 5: Robustness checks: 2SLS-estimates of the (negative) elasticity of substitution between natives and foreigners

\begin{tabular}{lccc}
\hline & Denmark & Germany & UK $^{\mathrm{c}}$ \\
\hline Baseline & $-16.906^{* * *}$ & $-6.713^{* * *}$ & $-8.891^{* * *}$ \\
& $(2.259)$ & $(0.802)$ & $(1.248)$ \\
OLS & $-7.638^{* * *}$ & $-2.571^{* * *}$ & $-2.916^{* * *}$ \\
& $(0.610)$ & $(0.382)$ & $(0.246)$ \\
Log mean wages & $-16.676^{* * *}$ & $-6.322^{* * *}$ & $-8.734^{* * *}$ \\
& $(2.059)$ & $(0.759)$ & $(1.146)$ \\
Cell size weighted & $-13.538^{* * *}$ & $-7.977^{* * *}$ & $-10.680^{* * *}$ \\
& $(1.674)$ & $(1.100)$ & $(2.673)$ \\
Occupation & $-13.360^{* * *}$ & $-5.768^{* * *}$ & $-16.601^{* * *}$ \\
& $(1.240)$ & $(0.754)$ & $(2.580)$ \\
Revised experience & $-14.701^{* * *}$ & $-6.439^{* * *}$ & $-9.615^{* *}$ \\
Occupupation & $(2.081)$ & $(0.912)$ & $(4.464)$ \\
and revised experience & $(1.849)$ & $-6.719^{* * *}$ & $-25.049^{* *}$ \\
\hline
\end{tabular}

Standard errors in parentheses.- ${ }^{* * *},{ }^{* *},{ }^{*}$ denote the $1 \%^{-}, 5 \%^{-}, 10 \%-$ significance levels, respectively.

First, we have estimated our model by OLS. The coefficients still appear highly significant in all three countries, but have only between one-third and 50 percent of the size of the 2SLS estimates. Nevertheless, against the background of our theoretical considerations, we believe that the OLS estimates are downward biased.

Second, we proved whether our findings respond sensitively with respect to the specification of the dependent variable. Borjas et al. (2012) claim that the scale of the elasticity depends inter alia largely on whether the log of mean wages or the mean of log wages is used as the dependent variable since the the first measure is more vulnerable to sampling error. This is not supported by our findings: Using the mean log wage delivers only marginally different results compared to regressions which employ the log mean wage as the dependent variable.

Third, we have replaced the analytical weight in our regressions. While the baseline specification follows Borjas et al. (2012) in using the inverse variance of the log wage ratio as the weight, we use here following Ottaviano and Peri (2012) the average cell size measured by the number of employed workers as an alternative. This delivers somewhat larger coefficients in the case of Germany and the UK, and a smaller one in Denmark. However, the differences are within the limits of one standard deviation in case of Germany and the UK, and only slightly larger in the case of Denmark.

Fourth, the classification of education groups can bias our results if immigrants are severely affected by skill-downgrading. We have therefore reclassified the education groups by occupation in order to avoid that misclassification affects our findings. The results are 
mixed: While classifying individuals by occupation delivers smaller elasticities in case of Denmark and Germany, the elasticity increases substantially in the UK:

Finally, there is ample evidence that downgrading can also affect work experience. Dustmann and Preston (2012) finds that the returns to work experience of immigrants are well below those of natives in the first tend years after arrival, but tend to converge largely after that time period. As a robustness check, we reclassified therefore the work experience: During the first ten years after arrival, we counted only the work experience obtained in the host country. ${ }^{20}$ After that, we counted the entire work experience. Albeit crude, this reclassification should at least provide a hint how robust our findings are. Interestingly enough, the reclassification of experience groups does not largely change the results in Germany and the UK, and reduces only slightly the elasticity in Denmark.

Altogether, we conclude that our estimates are relatively robust with respect to different definitions of the dependent variable, weighting schemes and classifications of education and experience groups.

In the next step we estimate the elasticity of substitution between experience groups. Using equation (13) we can estimate the demand for the labor composite $L_{q j t}$ as

$$
\ln L_{q j t}=D_{t}+D_{q t}+D_{q j}-\rho \ln w_{q j t}+v_{q j t},
$$

where the $D_{t}$ fixed effects control for the variance of

$$
\rho \ln \left(\nu^{-1} \alpha A_{t}^{1 / \alpha} \kappa_{t}^{(1-\alpha) / \alpha}\right)+\frac{\rho}{\delta} \ln L_{t},
$$

the $D_{q t}$ fixed effects control for the variation in

$$
\rho \ln \theta_{q t}-\left(\frac{\rho}{\delta}-1\right) \ln L_{q t}
$$

and the $D_{q j}$ fixed effects control for the variance in $\rho \ln \theta_{q j}$ (the productivity term times the elasticity of substitution), which is assumed to be constant over time. $v_{q j t}$ denotes the zero-mean disturbance.

The labor composite is then calculated as

$$
\hat{L}_{q j t}=\left[\hat{\theta}_{q j 1} L_{q j 1 t}^{(\hat{\sigma}-1) / \hat{\sigma}}+\hat{\theta}_{q j 2} L_{q j 2 t}^{(\hat{\sigma}-1) / \hat{\sigma}}\right]^{\hat{\sigma} /(\hat{\sigma}-1)}
$$

where we use our estimates of the education-experience-specific fixed effects from equation (14) to calculate the productivity parameters for native and foreign workers as

$$
\hat{\theta}_{q j 1}=\frac{\exp \left(\hat{D}_{q j} / \hat{\sigma}\right)}{1+\exp \left(\hat{D}_{q j} / \hat{\sigma}\right)}
$$

\footnotetext{
${ }^{20}$ In Denmark and Germany, the administrative data provide no information on the year of arrival We used the information on the first observation in the data set instead. Given the long time dimension of these data set, we can rule out that individuals have participated in the labour force before that date.
} 
and

$$
\hat{\theta}_{q j 2}=\frac{1}{1+\exp \left(\hat{D}_{q j} / \hat{\sigma}\right)}
$$

We estimate equation (15) by 2SLS since it might be again suffer from simultaneous equation bias. We apply in each country the same instrumental variables as in the estimates for the elasticity of substitution between natives and immigrants: the age of the youngest child in Denmark, the average number of children in the age group eight to sixteen in Germany and the mean household income of the unemployed in the UK. All measures are calculated for each education-experience group. Note that we can not use macro instruments such as the government ideology index or the minimum wage here, since these variables would be perfectly collinear with the time-fixed effects.

Table 6: 2SLS estimates of the elasticity of substitution across education-experience groups

\begin{tabular}{lccc}
\hline & Denmark $^{\mathrm{a}}$ & Germany $^{\mathrm{b}}$ & UK $^{\mathrm{c}}$ \\
\hline$-\rho$ & $-7.740^{* * *}$ & $-5.569^{* *}$ & $-7.148^{*}$ \\
& $(1.604)$ & $(2.465)$ & $(4.093)$ \\
\hline Kleibergen-Paap F-statistic & 24.82 & 30.59 & 4.61 \\
Kleibergen-Paap LM-statistic & 17.90 & 20.32 & 3.31 \\
$\mathrm{R}^{2}$ & 0.99 & 0.98 & 0.96 \\
Observations & 204 & 216 & 216 \\
\hline
\end{tabular}

\footnotetext{
Heteroskedasticity-robust standard errors in parentheses. - ***, **, * denote the 1\%-, 5\%-, 10\%-significance levels, respectively. - All estimations include a full set of education-experience controls, time controls and education specific time dummies. All estimations are weighted (see main text).

a Instrument: Average age of youngest child of employed workers within each education-experience group.

b Instrument: Average number of children of employed workers in age between 8 and 16 within each education-experience group.

${ }^{c}$ Instrument: Median household income of the unemployed within each educationexperience group.
}

The estimates of (15) are exactly identified, such that we cannot test for the validity of our instruments. The $F$-test statistics suggests that our IVs are strong in case of Denmark and Germany, but this is not to be the case in the UK: The regression results have to be taken with a grain of salt there. The results indicate that the elasticity of substitution across experience cells is highest in Denmark $(-7.7)$, followed by the UK $(-7.1)$ and Germany (-5.5). The results for Germany are higher than those found by D'Amuri et al. (2010) (-3.2), but below the estimates by Brücker and Jahn (2011) (-8.6) and Felbermayr et al. (2010) (-13.0). In the UK the results are somewhat larger than those obtained by Manacorda et al. (2012) (-5.1).

Overall, our results for all three countries are consistent with those found using the standard identification strategy in the international literature (see e.g. Katz and Murphy, 1992, Card and Lemieux, 2001, Borjas, 2003, Ottaviano and Peri, 2012). 
Finally, the elasticity of substitution between education groups is estimated analogously as

$$
\ln \hat{L}_{q t}=D_{t}+D_{q}+\beta_{q} \tau_{q t}-\delta \ln w_{q t}+\xi_{q t},
$$

where the time-specific fixed effects $D_{t}$ control for the variance of

$$
\delta \ln \left(\nu^{-1} \alpha A_{t}^{1 / \alpha} \kappa_{t}^{(1-\alpha) / \alpha}\right)+\ln L_{t}
$$

and other macroeconomic fluctuations. The education-specific fixed effects $D_{q}$ and the education-specific deterministic time trend $\tau_{q t}$ control for the variance in the term $\delta \ln \theta_{q t}$, which captures the variance in the skill-specific productivity parameter which is driven, inter alia, by skill-biased technological progress (see Katz and Murphy, 1992 for a similar specification). $\xi_{q t}$ denotes a zero-mean random disturbance.

The labor composite $\hat{L}_{q t}$ is computed as

$$
\hat{L}_{q t}=\left[\sum_{j=1}^{4} \hat{\theta}_{q j} \hat{L}_{q j t}^{(\hat{\rho}-1) / \hat{\rho}}\right]^{\hat{\rho} /(\hat{\rho}-1)}
$$

where the estimated efficiency parameters $\hat{\theta}_{q j}$ are derived from the fixed-effects estimates as

$$
\hat{\theta}_{q j}=\frac{\exp \left(\hat{D}_{q j} / \hat{\rho}\right)}{\sum_{j} \exp \left(\hat{D}_{q j} / \hat{\rho}\right)}
$$

We estimate equation (16) again by 2SLS using the average age of the youngest child, the average number of children in the age group between eight and sixteen and the median household income in each education group in Denmark, Germany and the UK, respectively, as instruments.

The regression diagnostics presented in Table 7 suggests that the instruments are strong and reject the hypothesis of underidentification in all three countries. The estimated elasticity of substitution between education groups is again largest in Germany (-4.4) followed by the UK (-4.0) and Denmark (-2.7). Our results for Germany are somewhat higher than those found by Brücker and Jahn (2011) (-2.9) and D'Amuri et al. (2010) $(-2.9)$, while those found in the UK are slightly than those found by Manacorda et al. (2012) (-4.9).

In summary, we find that - as predicted by our nested CES-production function the elasticity of substitution between natives and foreigners is larger than the elasticity of substitution between experience groups, and that the elasticity of substitution between experience groups is larger than that between education groups. The estimates from our 2SLS regressions deliver overall comparable results for the elasticities of substitution between natives and immigrants found in other studies for Germany and the UK. The 
Table 7: 2SLS estimates of the elasticity of substitution between education groups

\begin{tabular}{lccc}
\hline & Denmark $^{\mathrm{a}}$ & Germany $^{\mathrm{b}}$ & UK $^{\mathrm{c}}$ \\
\hline$-\delta$ & $-2.711^{* * *}$ & $-4.356^{* * *}$ & $-3.950^{* * *}$ \\
& $(0.958)$ & $(0.651)$ & $(0.253)$ \\
\hline Kleibergen-Paap F-statistic & 118.56 & 72.90 & 51.02 \\
Kleibergen-Paap LM-statistic & 13.71 & 7.89 & 21.71 \\
$\mathrm{R}^{2}$ & 0.91 & 0.80 & 0.96 \\
Observations & 51 & 54 & 54 \\
\hline
\end{tabular}

Heteroskedasticity-robust standard errors in parentheses. _ ***, **, * denote the 1\%-, 5\%-, 10\%-significance levels, respectively. - All estimations include a full set of time controls and an education specific deterministic time trend. All estimations are weighted (see main text).

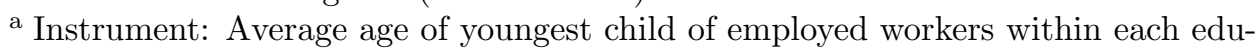
cation group.

b Instrument: Average number of children of employed workers in age between 8 and 16 within each education group.

c Instrument: Median household income of the unemployed within each education group.

OLS estimates are substantially lower, but we believe that simultaneous equation biases requires an instrumental variable estimation strategy. The estimates for the elasticities are by and large also in the range of other findings in the literature.

\section{Simulating the impact of immigration}

To calculate the wage effects of a labor supply shock due to immigration, we first compute the employment effects. The general solution for the employment effects is given in equation (6), and an explicit solution for our case with 24 types of labor and a nested CES production function is provided in Appendix A.

In the second step, we differentiate the wage equation (13) with respect to the employment changes in all cells of the labor market and with respect to a change in the capital-output ratio triggered by immigration. This gives us the wage response to immigration: 


$$
\begin{aligned}
\frac{d w_{q j k t}}{w_{q j k t}} & =\frac{1}{\delta} \sum_{z} \sum_{x} \sum_{m}\left(s_{z x m t} \frac{d L_{z x m t}}{L_{z x m t}}\right) \\
& -\left(\frac{1}{\delta}-\frac{1}{\rho}\right) \frac{1}{s_{q t}} \sum_{x} \sum_{m}\left(s_{q x m t} \frac{d L_{q x m t}}{L_{q x m t}}\right) \\
& -\left(\frac{1}{\rho}-\frac{1}{\sigma}\right) \frac{1}{s_{q j t}} \sum_{m}\left(s_{q j m t} \frac{d L_{q j m t}}{L_{q j m t}}\right) \\
& -\frac{1}{\sigma_{q}}\left(\frac{d L_{q j k t}}{L_{q j k t}}\right)+\frac{1-\alpha}{\alpha} \frac{d \kappa_{t}}{\kappa_{t}}
\end{aligned}
$$

where $z=1, \ldots, 3$ indexes education, $x=1, \ldots, 4$ work experience, $m=1,2$ national origin, and $s$ denotes the share of wages paid to workers in the respective labor market cell in the total wage bill:

$$
\begin{aligned}
s_{q j k t} & =\frac{w_{q j k t} L_{q j k t}}{\sum_{z} \sum_{x} \sum_{m} w_{z x m t} L_{z x m t}}, \\
s_{q j t} & =\frac{\sum_{m} w_{q j m t} L_{q j m t}}{\sum_{z} \sum_{x} \sum_{m} w_{z x m t} L_{z x m t}}, \\
s_{q t} & =\frac{\sum_{x} \sum_{m} w_{q x m t} L_{q x m t}}{\sum_{z} \sum_{x} \sum_{m} w_{z x m t} L_{z x m t}} .
\end{aligned}
$$

In this section we simulate the case of a one percent labor supply shock through immigration at the education-experience structure of the immigrant labor force at the end of the sample periods. Our simulations are based on the elasticities of the wage-setting curves in the different segments of the labor market, and the elasticities of substitution between natives and foreigners, experience and education groups. For the simulation of the labor supply shock we use the education and experience structure of the foreign labor force at the end of the sample period in each country.

We simulate both a short- and a long-run scenario. In the simulations of the short-run impact of immigration we assume that the capital stock remains fixed. In the longrun simulations we assume that the capital stock adjusts completely to an aggregate labor supply shock, such that the capital-output ratio is fixed. The latter assumption is empirically supported by the Kaldor facts on economic growth and can be explained, inter alia, by international capital mobility (see Ottaviano and Peri, 2012, for a discussion). Note that empirical estimates suggest that the capital stock adjusts rather fast to labor supply changes (see Brücker and Jahn, 2008, for German evidence, and Ottaviano and Peri, 2012, Ottaviano and Peri, 2008 for US evidence).

The parameters for the wage-setting curves are taken from our estimates of equation (8) and the estimates of $\sigma, \rho$, and $\delta$ from equations (14) - (16). Following the literature, we set $\alpha$ to 0.67 (e.g. Cahuc and Zylberberg, 2001). Having calculated the employment effects 
of immigration, we use equation (13) for the calculation of the wage effect. The shares of education and education-experience groups in the total wage bill are taken from our data sets. Note that the mark-up factor is a constant that cancels out when we calculate changes of wage and (un-)employment levels.

Finally, we provide standard errors for our simulations. The standard errors are obtained by a bootstrapping procedure, which draws first for each parameter 1000 values from a normal distribution with mean and standard deviation being equal to the estimated coefficient and standard error, respectively. Then the model is simulated 1000 times and the mean and standard deviation of all simulations are reported in the table.

Table 8 presents the simulation results for Denmark, Germany, and the UK. We have calculated the average effects for the total labor force, the native labor force, and the foreign labor force by educational levels. For the calculation of the average effects, we weight the wage changes by the income share in each cell, and the changes in the unemployment rate by the share in the labor force in each cell.

The aggregate results indicate that a one percent immigration reduces wages in the UK by $0.26 \%$, by $0.22 \%$ in Denmark and only by $0.14 \%$ in Germany in the short-term. In the long-run scenario, the aggregate wage effects disappear by assumption. Note that this assumption is however empirically supported by the Kaldor facts and the empirical evidency provided by Brücker and Jahn (2008) and Ottaviano and Peri (2008, 2012).

For the unemployment rate, the opposite picture emerges. We find that a one percent labor supply shock through immigration increases the unemployment rate in the short term by 0.36 percentage points in Germany, but by 0.18 percentage points in Denmark and 0.20 percentage points in the UK. In the first place, this result can be traced back to the different elasticities of the wage-setting curves in our three countries. Differences in the labor supply shocks across education, experience and national origin cells of the labor market play also a role. The skill level of the immigrant workforce is particularly low in Germany, such that the labor supply shock affects labor market cells with low wage flexibility and high unemployment. In contrast, immigrants are relatively skilled in the UK, such that immigration involves large wage and low unemployment effects there. In the long-term, after the adjustment of capital stocks, we find that the unemployment rate increases by 0.17 percentage points in Germany and by 0.13 percentage points in Denmark, while it declines slightly by 0.10 percentage points in the UK. Note that migration can involve changes in the unemployment rate even after the adjustment of capital stocks if the composition of the workforce, and, hence, the unemployment risks of the labor force changes. While immigrants increase the labor supply in segments with less wage flexibility and higher unemployment in Denmark and Germany, the reverse is true for the UK. 


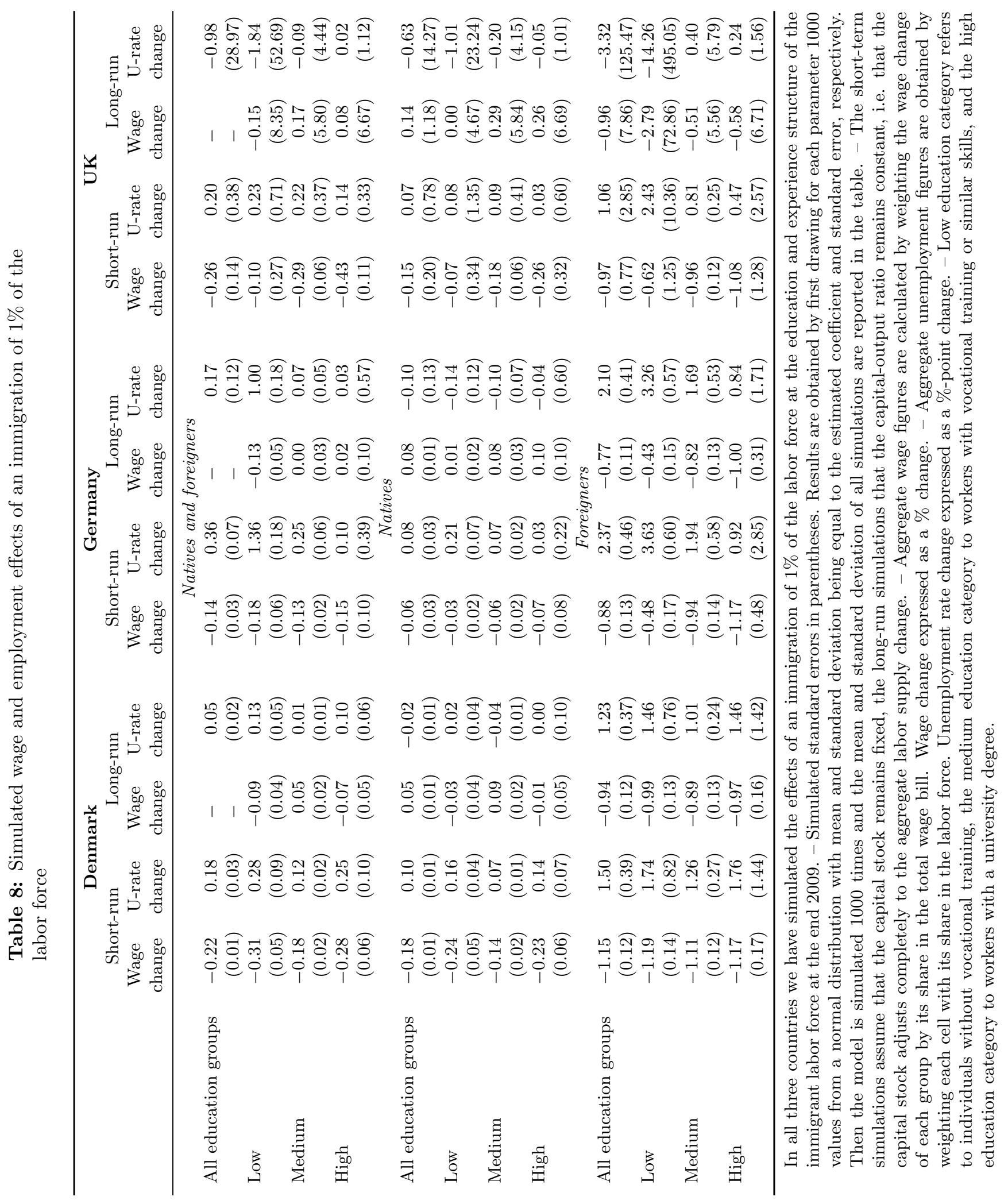


Table 8 presents the simulation results for Denmark, Germany, and the UK. We have calculated the average effects for the total labor force, the native labor force, and the foreign labor force by educational levels. For the calculation of the average effects, we weight the wage changes by the income share in each cell, and the changes in the unemployment rate by the share in the labor force in each cell.

The aggregate results indicate that a one percent immigration reduces wages in the UK by $0.29 \%$, but only by $0.15 \%$ in Denmark and by $0.16 \%$ in Germany in the short-term. However, the Kaldor facts and the empirical findings by Ottaviano and Peri (2012) and others suggest that capital stocks adjust fast to labor supply shocks, if not immediately. Not surprisingly, the aggregate wage effects of immigration disappear completely after capital stock adjustment in all three countries.

For the unemployment rate, the opposite picture emerges. We find that a one percent labor supply shock through immigration increases the unemployment rate in the short term by 0.35 percentage points in Germany, by 0.20 percentage points in Denmark, but only by 0.11 percentage points in the UK. In the first place, this result can be traced back to the different elasticities of the wage-setting curves in our three countries. Differences in the labor supply shocks across education, experience and national origin cells of the labor market play also a role. The skill level of the immigrant workforce is particularly low in Germany, such that the labor supply shock affects labor market cells with low wage flexibility and high unemployment. In contrast, immigrants are relatively skilled in the UK, such that immigration involves large wage and low unemployment effects there. In the long-term, after the adjustment of capital stocks, we find that the unemployment rate increases by 0.17 percentage points in Germany and by 0.13 percentage points in Denmark, while it declines slightly by 0.10 percentage points in the UK. Note that migration can involve changes in the unemployment rate even after the adjustment of capital stocks if the composition of the workforce, and, hence, the unemployment risks of the labor force changes. While immigrants increase the labor supply in segments with less wage flexibility and higher unemployment in Denmark and Germany, the reverse is true for the UK. 
Table 9: Simulated wage effects of an immigration of $1 \%$ of the labor force

\begin{tabular}{|c|c|c|c|c|c|c|}
\hline & \multicolumn{2}{|c|}{ Denmark } & \multicolumn{2}{|c|}{ Germany } & \multicolumn{2}{|c|}{ UK } \\
\hline & $\begin{array}{l}\text { Short-run } \\
\text { Wage } \\
\text { change }\end{array}$ & $\begin{array}{l}\text { Long-run } \\
\text { Wage } \\
\text { change }\end{array}$ & $\begin{array}{l}\text { Short-run } \\
\text { Wage } \\
\text { change }\end{array}$ & $\begin{array}{l}\text { Long-run } \\
\text { Wage } \\
\text { change }\end{array}$ & $\begin{array}{l}\text { Short-run } \\
\text { Wage } \\
\text { change }\end{array}$ & $\begin{array}{l}\text { Long-run } \\
\text { Wage } \\
\text { change }\end{array}$ \\
\hline & \multicolumn{6}{|c|}{ Natives and foreigners } \\
\hline All education groups & -0.28 & - & -0.25 & - & -0.33 & - \\
\hline & $(0.00)$ & - & $(0.00)$ & - & $(0.00)$ & - \\
\hline Low $^{\mathrm{e}}$ & $\begin{array}{c}-0.41 \\
(0.28)\end{array}$ & $\begin{array}{c}-0.13 \\
(0.28)\end{array}$ & $\begin{array}{c}-0.72 \\
(0.07)\end{array}$ & $\begin{array}{c}-0.47 \\
(0.07)\end{array}$ & $\begin{array}{c}-0.18 \\
(0.01)\end{array}$ & $\begin{array}{c}0.15 \\
(0.01)\end{array}$ \\
\hline Medium $^{\mathrm{e}}$ & $\begin{array}{c}-0.22 \\
(0.14)\end{array}$ & $\begin{array}{c}0.07 \\
(0.14)\end{array}$ & $\begin{array}{c}-0.23 \\
(0.00)\end{array}$ & $\begin{array}{c}0.02 \\
(0.00)\end{array}$ & $\begin{array}{c}-0.36 \\
(0.00)\end{array}$ & $\begin{array}{c}-0.04 \\
(0.00)\end{array}$ \\
\hline $\operatorname{High}^{\mathrm{e}}$ & $\begin{array}{c}-0.37 \\
(0.19)\end{array}$ & $\begin{array}{c}-0.09 \\
(0.19)\end{array}$ & $\begin{array}{c}-0.21 \\
(0.01) \\
\text { Nat }\end{array}$ & $\begin{array}{c}0.05 \\
\text { ves }\end{array}$ & $\begin{array}{c}-0.48 \\
(0.01)\end{array}$ & $\begin{array}{c}-0.16 \\
(0.01)\end{array}$ \\
\hline All education groups & $\begin{array}{c}-0.23 \\
(0.01)\end{array}$ & $\begin{array}{c}0.05 \\
(0.01)\end{array}$ & $\begin{array}{c}-0.13 \\
(0.01)\end{array}$ & $\begin{array}{c}0.12 \\
(0.01)\end{array}$ & $\begin{array}{c}-0.21 \\
(0.02)\end{array}$ & $\begin{array}{c}0.12 \\
(0.02)\end{array}$ \\
\hline Low & $\begin{array}{c}-0.34 \\
(0.28)\end{array}$ & $\begin{array}{c}-0.06 \\
(0.28)\end{array}$ & $\begin{array}{c}-0.30 \\
(0.12)\end{array}$ & $\begin{array}{c}-0.05 \\
(0.12)\end{array}$ & $\begin{array}{c}-0.13 \\
(0.01)\end{array}$ & $\begin{array}{c}0.19 \\
(0.01)\end{array}$ \\
\hline Medium & $\begin{array}{r}-0.18 \\
(0.14)\end{array}$ & $\begin{array}{c}0.11 \\
(0.14)\end{array}$ & $\begin{array}{c}-0.13 \\
(0.01)\end{array}$ & $\begin{array}{c}0.12 \\
(0.01)\end{array}$ & $\begin{array}{c}-0.23 \\
(0.02)\end{array}$ & $\begin{array}{c}0.09 \\
(0.02)\end{array}$ \\
\hline High & $\begin{array}{c}-0.31 \\
(0.19)\end{array}$ & $\begin{array}{c}-0.02 \\
(0.19)\end{array}$ & $\begin{array}{c}-0.12 \\
(0.01)\end{array}$ & $\begin{array}{c}0.13 \\
(0.01)\end{array}$ & $\begin{array}{c}-0.30 \\
(0.04)\end{array}$ & $\begin{array}{c}0.03 \\
(0.04)\end{array}$ \\
\hline & \multicolumn{6}{|c|}{ Foreigners } \\
\hline All education groups & $\begin{array}{c}-1.31 \\
(0.15)\end{array}$ & $\begin{array}{c}-1.02 \\
(0.15)\end{array}$ & $\begin{array}{c}-1.41 \\
(0.14)\end{array}$ & $\begin{array}{c}-1.16 \\
(0.14)\end{array}$ & $\begin{array}{c}-1.13 \\
(0.13)\end{array}$ & $\begin{array}{c}-0.80 \\
(0.13)\end{array}$ \\
\hline Low & $\begin{array}{c}-1.41 \\
(0.32)\end{array}$ & $\begin{array}{c}-1.13 \\
(0.32)\end{array}$ & $\begin{array}{c}-1.55 \\
(0.21)\end{array}$ & $\begin{array}{c}-1.30 \\
(0.21)\end{array}$ & $\begin{array}{c}-1.00 \\
(0.12)\end{array}$ & $\begin{array}{c}-0.68 \\
(0.12)\end{array}$ \\
\hline Medium & $\begin{array}{c}-1.23 \\
(0.19)\end{array}$ & $\begin{array}{c}-0.95 \\
(0.19)\end{array}$ & $\begin{array}{c}-1.37 \\
(0.14)\end{array}$ & $\begin{array}{c}-1.12 \\
(0.14)\end{array}$ & $\begin{array}{c}-1.10 \\
(0.11)\end{array}$ & $\begin{array}{c}-0.78 \\
(0.11)\end{array}$ \\
\hline High & $\begin{array}{c}-1.36 \\
(0.24)\end{array}$ & $\begin{array}{c}-1.08 \\
(0.24)\end{array}$ & $\begin{array}{c}-1.36 \\
(0.15)\end{array}$ & $\begin{array}{c}-1.11 \\
(0.15)\end{array}$ & $\begin{array}{c}-1.18 \\
(0.15)\end{array}$ & $\begin{array}{r}-0.85 \\
(0.15)\end{array}$ \\
\hline
\end{tabular}

See notes in Table 8 
In all three countries we observe that native workers benefit both in terms of higher wages and lower unemployment risks from immigration, at least in the long-term. This is caused by the limited elasticity of substitution between native and foreign workers in each education-experience cell of the labor market and by differences in the skill and experience composition of the native and immigrant workforce. The results are particularly large in the UK case, where native wages increase by $0.11 \%$ and the unemployment risk of natives declines by 0.22 percentage points.

Earlier migrants are the main losers from further immigration. Their wages decline by $1.7 \%$ in Denmark, $1.4 \%$ in Germany and $1.2 \%$ in the UK, while their unemployment rates increase by 2.5 percentage points in Denmark, 3.0 percentage points in Germany and 0.9 percentage points in the UK in the short-term. The long-term effects are only slightly smaller. The differences across the three countries can be explained both by the different elasticities of substitution between natives and foreigners and by the different elasticities of the wage-setting curves. In particular, there are less pronounced effects in the UK since the elasticity of substitution between natives and foreigners is much higher there compared to the other two countries. Altogether, we can conclude that the existing foreign workforce suffers from immigration, while the native workforce tends to benefit.

Finally, we find different effects in different education groups across the three countries considered here. In Germany we find particularly large wage and unemployment effects in the less-skilled segment of the labor market, while the high-skilled are more affected in the UK, and, to a lesser extent, in Denmark. These differences between the three countries are caused by the different skill structure of the foreign workforce, and, hence, the different skill structure of the simulated labor supply shocks.

\section{Conclusions}

The great majority of existing studies on the wage effects of migration rely on the assumption of clearing labor markets. Therefore, they do not consider the role of labor market institutions and policies in shaping the impact of migration. Nor do they allow a role for unemployment. Because institutions and policies differ significantly between countries, in this paper we take a comparative perspective in a setting with imperfect labor markets. We apply an estimation and instrumentation strategy which does not rely on the assumption of clearing labor markets, and we derive the wage and unemployment effects simultaneously from a coherent framework which considers wage rigidities.

Our findings suggest that labor market institutions do play an important role in determining the wage and employment effects of immigration. In the UK, where labor markets are characterized (both in the literature and according to our estimates) by a high level of wage flexibility we find the highest elasticity between wages and unemployment, followed by Germany and Denmark. Interestingly, we find that wage flexibility is particularly low 
in Denmark. This can be explained by a higher union density, a higher coverage of collective bargaining and higher unemployment benefits compared to the other countries, although employment protection is weak and the level of centralized collective bargaining is similar to that of Germany. Another intriguing finding is that the elasticity between wages and unemployment tends to increase monotonically with the skill level of workers in Germany and the UK, while it tends to decline in Denmark. While the former result can be explained by a lower union density and coverage of collective bargaining in the high skilled segments of the labor markets in Germany and the UK, the latter finding might be caused by the progressive tax system and the high level of union density and collective bargaining coverage for high skilled workers in Denmark.

As a consequence of the varying degrees of wage flexibility we find considerable differences in the effects of immigration on wages and employment in the three countries. Our estimates indicate that the impact of immigration on unemployment is particularly low in the UK in the short-term. However, the wage effects are about twice as high compared to Germany and Denmark, where the flexibility of labor markets, measured in terms of the elasticity of the wage-setting curve, is lower. Conversely, the short-term effects of immigration on unemployment exceed that of the UK by a factor of three in Germany and by a factor of two in Denmark. In the long term, under the empirically supported assumption that capital stocks adjust to labor supply shocks, immigration does not affect wages. However, since immigration affects the composition of the workforce, unemployment tends to increase slightly in Germany and Denmark and to decline in the UK. The latter finding can be traced back to the fact that immigration increases labor supply in the flexible segments of the labor market (i.e. the high-skilled segment) and creates additional labor demand in the less flexible segments in the UK. Due to the higher wage flexibility and the relatively skilled immigrant labor force the overall effects of immigration are therefore much more favorable in the UK compared to Germany and Denmark.

An important factor which affects our results is the labor market assimilation of immigrants, measured in terms of the elasticity of substitution between native and foreign workers. Again, the labor market assimilation of immigrants might be affected by institutions. As well as labor market and immigration policies which affect assimilation (such as language tuition or housing), job turnover may be a crucial factor in determining how quickly immigrants integrate into the labor market. Note that job turnover rates are much higher in the United Kingdom and Denmark compared to Germany (Bassanini and Marianna, 2009). This is supported by our findings: while the elasticity of substitution between immigrants and natives is relatively high in the United Kingdom and Denmark, it is particularly low in Germany. This elasticity is crucial in determining the wage and employment effects of further immigration. The impact on the immigrant workforce is relatively modest in the UK, where the elasticity of substitution is high, while the opposite is true for Germany, where the elasticity is particularly low. Although we find that the pre-existing immigrant workforce is the main loser from immigration, the magnitude of 
these effects differs significantly across countries. This suggests that labor market institutions which affect job turnover play an important role in the distribution of the effects of immigration across different groups in the labor market.

\section{References}

Altonji, J. and Card, D. (1991), "The effects of immigration on the labor market outcomes of less-skilled natives", in J. Abowd and R. Freeman, eds, Immigration Trade and the Labor Market, NBER, Chicago: University of Chicago Press, chapter 7.

Anderson, T. and Svarer, M. (2007), "Flexicurity - labour market performance in Denmark", CESifo Economic Studies 52(3), 389-429.

Aydemir, A. and Borjas, G. (2011), "Attenuation bias in measuring the wage impact of immigration", Journal of Labor Economics 29(1), 69-112.

Aydemir, A. and Borjas, G. J. (2007), "Cross-country variation in the impact of international migration: Canada, Mexico and the United States", Journal of the European Economic Association 5(4), 663-708.

Baldwin, R. and Wyplosz, C. (2012), The Economics of European Integration, Fourth edition, McGraw-Hill.

Bartik, T. (1991), Who benefits from state and local development policies?, Michigan: W.E. Upjohn Institute for Employment Research.

Bartik, T. (1993), "The effects of local labor demand on individual labor market outcomes for diffrerent demographic groups and the poor", Upjohn Working Papers 93-23.

Bassanini, A. and Marianna, P. (2009), "Looking inside the perpetual motion machine: How industry, firm and worker characteristics shape job and worker flows", OECD Social, Employment and Migration Working Paper 95.

Bell, B., Nickell, S. and Quintini, G. (2002), "Wage equations, wage curves and all that", Labour Economics 9(3), 341-360.

Bjørnskov, C. (2008), "The growth-inequality association: Government ideology matters", Journal of Development Economics 87(2), 300-308.

Blanchard, O. and Katz, L. (1992), "Regional evolutions", Brookings Papers on Economic Activity 1:1992, 1-75.

Blanchflower, D. and Oswald, A. (1994), The wage curve, Cambridge, MA: MIT Press.

Blanchflower, D. and Oswald, A. (2005), "The wage curve: reloaded", NBER working paper 11338.

Boeri, T. and Brücker, H. (2005), "Why are Europeans so tough on migrants?", Economic Policy 20(44), 631-703.

Borjas, G. (1987), "Immigrants, minorities and labor market compeition", Industrial and Labor Relations Review 40, 382-392. 
Borjas, G. (2003), "The labor demand curve is downward sloping: re-examining the impact of immigration on the labor market", Quarterly Journal of Economics 68(4), 1335-1374.

Borjas, G., Freeman, R. and Katz, L. (1996), "Searching for the effect of immigration on the labor market", American Economic Review 86(2), 246-251.

Borjas, G., Freeman, R. and Katz, L. (1997), "How much do immigration and trade affect labor market outcomes?", Brookings Papers on Economic Activity 1, 1-67.

Borjas, G. J., Grogger, J. and Hanson, G. H. (2008), "Imperfect substitution between immigrants and natives: a reappraisal", NBER working paper 13887.

Borjas, G. J., Grogger, J. and Hanson, G. H. (2012), "Comment: On estimating elasticities of substitution", Journal of the European Economic Association 10(1), 198-210.

Bound, J. and Holczer, H. J. (2000), "Demand shifts, population adjustments, and labor market outcomes during the 1980s", Journal of Labor Economics 18(1), 20-54.

Brücker, H. and Jahn, E. (2008), "Migration and the wage curve: a structural approach to measure the wage and employment effects of migration", IZA Discussion Paper 3423.

Brücker, H. and Jahn, E. (2011), "Migration and wage-setting: Reassessing the labor market effects of migration", Scandinavian Journal of Economics 113(2), 286-317.

Büttner, T. and Rässler, S. (2008), "Multiple imputation of right-censored wages in the German IAB employment sample considering heteroscedasticity", IAB Discussion Paper $44 / 2008$.

Cahuc, P. and Zylberberg, A. (2001), "The consequences of the minimum wage when other wages are bargained over", European Economic Review 45(2), 337-352.

Card, D. (1990), "The impact of the Mariel boatlift on the Miami labour market", Industrial and Labor Relations Review 43(2), 245-257.

Card, D. (1995), "The Wage Curve: a review", Journal of Economic Literature 33, 785799.

Card, D. (2001), "Immigrant inflows, native outflows, and the local labor market impacts of higher immigration", Journal of Labor Economics 19, 22-63.

Card, D. (2005), "Is the new immigration really so bad?", Economics Letters 115, F300F323.

Card, D. (2012), "Comment: The elusive search for negative wage impacts of immigration", Journal of the European Economic Association 10(1), 211-215.

Card, D. and DiNardo, J. (2000), "Do immigrant inflows lead to native outflows?", American Economic Review 90(2), 360-367.

Card, D. and Lemieux, T. (2001), "Can falling supply explain the rising return to college for younger men? A cohort based analysis", Quarterly Journal of Economics 116(2), 705-746.

Card, D. and Schleifer, A. (2009), "Immigration and inequality", American Economic Review 99(2), 1-21. 
Carlsson, M., Eriksson, S. and Gottfries, N. (2006), "Testing theories of job creation: Does supply create its own demand?", IZA Discussionpaper 2024.

Carlsson, M., Eriksson, S. and Gottfries, N. (2008), "How important are search frictions for employment dynamics?", Mimeo, Uppsala University.

D'Amuri, F., Ottaviano, G. and Peri, G. (2010), "The labor market impact of immigration in Western Germany in the 1990s", European Economic Review 54(4), 550-570.

Dorner, M., Heining, J., Jacobebbinghaus, P. and Seth, S. (2010), "Sample of integrated labour market biographies 1975-2008", Schmollers Jahrbuch 130, 599-608.

Dustmann, C., Fabbri, F. and Preston, I. (2005), "The impact of immigration on the British labour market", The Economic Journal 115(507), F324-F341.

Dustmann, C., Frattini, T. and Preston, I. (2008), "The effect of immigration along the distribution of wages", Centre for Research and Analysis of Migration discussion paper 03/08.

Dustmann, C. and Preston, I. (2012), "Comment: Estimating the effect of immigration on wages", Journal of the European Economic Association 10(1), 216-223.

Felbermayr, G., Geis, W. and Kohler, W. (2010), "Absorbing German immigration: wages and employment", Review of World Economics 146(1), 1-21.

Fitzenberger, B., Osikominu, A. and Völter, R. (2006), "Imputation rules to improve the education variable in the IAB employment subsample", Schmollers Jahrbuch 126(3), 405-436.

Forslund, A., Gottfries, N. and Westermark, A. (2008), "Prices, productivity, and wage bargaining in open economies", 110(1), 169-195.

Friedberg, R. and Hunt, J. (1995), "The impact of immigrants on host country wages, employment and growth", Journal of Economic Perspectives 9(2), 23-44.

Glitz, A. (2012), "The labor market impact of immigration: A quasi-experiment exploiting immigrant location rules in germany", Journal of Labor Economics 30(1), 175-213.

Grossman, J. (1982), "The substitutability of natives and immigrants in production", Review of Economics and Statistics 64(4), 596-603.

Katz, L. and Murphy, K. (1992), "Changes in relative wages, 1963-1987: supply and demand factors", Quarterly Journal of Economics 107(1), 35-78.

Krugman, P., Obstefeld, M. and Melitz, M. (2011), Internal Economics. Theory and Pol$i c y$, 9th edition, Pearson.

Kugler, A. and Yuksel, M. (2009), "Effects of low-skilled immigration on u.s. natives: Evidence from hurricane mitch", NBER Working Paper 14293.

Layard, R. and Nickell, S. (1986), "Unemployment in Britain", Economica 53(210 Supplement), S121-S169.

Layard, R., Nickell, S. and Jackman, R. (2005), Unemployment: Macroeconomic Performance and the Labour Market, 2nd edn, Oxford: Oxford University Press. 
Levine, P. (1999), "The welfare economics of migration control", Journal of Population Economics 12(1), 23-43.

Lindbeck, A. and Snower, D. (1987), "Efficiency wages versus insiders and outsiders", European Economic Review 31(1-2), 407-416.

Lindbeck, A. and Snower, D. (2001), "Insiders versus outsiders", Journal of Economic Perspectives 15(1), 165-188.

Lockwood, B., Sløk, T. and Tranæs, T. (2000), "Progressive taxation and wage setting: some evidence for Denmark", Scandinavian Journal of Economics 102(4), 707-723.

Longhi, S., Nijkamp, P. and Poot, J. (2005), "A meta-analytic assessment of the effect of immigration on wages", Journal of Economic Surveys 19(3), 451-477.

Longhi, S., Nijkamp, P. and Poot, J. (2006), "The impact of immigration on the employment of natives in regional labour markets: A meta-analysis", IZA discussion paper 2044 .

Longhi, S., Nijkamp, P. and Poot, J. (2008), "Meta-analysis of empirical evidence on the labor market impacts of immigration", IZA discussion paper 3418.

Manacorda, M., Manning, A. and Wadsworth, J. (2012), "The impact of immigration on the structure of male wages: Theory and evidence from Britain", Journal of the European Economic Association 10(1), 120-151.

Nickell, S. and Andrews, M. (1983), "Unions, real wages and employment in Britain 19511979", Oxford Economic Papers 35(Supplement), 183-206.

OECD (2011), "OECD STAT Database", http://stats.oecd.org.

OECD (2013), "OECD STAT Database", http://stats.oecd.org.

Office for National Statistics (2011), "Labour Force Survey User Guide", Volume 1: background and methodology.

Ottaviano, G. and Peri, G. (2008), "Immigration and national wages: Clarifying the theory and the empirics", NBER working paper 14188.

Ottaviano, G. and Peri, G. (2012), "Rethinking the effects of immigration on wages", Journal of the European Economic Association 10(1), 152-197.

Peri, G. and Sparber, C. (2011), "Assessing inherent model bias: An application to native displacement in response to immigration", Journal of Urban Economics 69, 82-91.

Pischke, S. and Velling, J. (1997), "Employment effects of immigration to Germany: an analysis based on local labor markets", Review of Economics and Statistics 79(4), 594604.

Saleheen, J. and Shadforth, C. (2006), "The characteristics of immigrants: a view of the data", Bank of England Quarterly Bulletin 46(4), 374-385.

Salop, S. (1979), "A model of the natural rate of unemployment", American Economic Review 69(1), 117-125. 
Shapiro, C. and Stiglitz, J. (1984), "Equilibrium unemployment as a worker discipline device", American Economic Review 74(3), 433-444.

Statistics Denmark (2007), "Integrated database for labour market research (IDA), latest update: January 25, 2007", http://www.dst.dk/.

Venn, D. (2009), "Legislation, collective bargaining and enforcement: Updating the OECD employment protection indicators", www.oecd.org/els/workingpapers.

World Bank (2013), "World Development Indicators (WDI) Database", Washington DC: World Bank. 


\section{A Technical Annex: Explicit solution for the employment response}

The general solution for the marginal employment response to an increase in labor supply through immigration is given in equation (6). The model in Section 2.2 distinguishes $3 \times$ $4 \times 2=24$ types of labor. Using the notation from the nested production function we write the vector as $\mathbf{x}=\left[x_{111}, x_{112}, x_{121}, \ldots, x_{211}, \ldots, x_{i j k}, \ldots, x_{342}\right]$, where $\mathbf{x} \in\left\{\mathbf{L}, \mathbf{N}, \mathbf{Y}_{\mathbf{L}}, \mathbf{u}, \mathbf{f}\right\}$. The subscript 111 therefore indexes the first, 112 the second, 121 the third, and 342 the 24 th element of each vector.

Thus, we can write the partial derivative of wages with respect to employment as

$$
\frac{\partial \mathbf{Y}_{\mathbf{L}}}{\partial \mathbf{L}}=\left[\begin{array}{lllll}
\frac{\partial Y_{L 111}}{\partial L_{111}} & \cdots & \frac{\partial Y_{L 111}}{\partial L_{i j k}} & \cdots & \frac{\partial Y_{L 111}}{\partial L_{342}} \\
\vdots & & \vdots & & \vdots \\
\frac{\partial Y_{L i j k}}{\partial L_{111}} & \cdots & \frac{\partial Y_{L i j k}}{\partial L_{i j k}} & \cdots & \frac{\partial Y_{L i j k}}{\partial L_{342}} \\
\vdots & & \vdots & & \vdots \\
\frac{\partial Y_{L 342}}{\partial L_{111}} & \cdots & \frac{\partial Y_{L 342}}{\partial L_{i j k}} & \cdots & \frac{\partial Y_{L 342}}{\partial L_{342}}
\end{array}\right]
$$

Due to the nested structure of the production function we have four types of partial derivatives in equation (A.1):

$$
\begin{aligned}
\frac{\partial Y_{L_{q j k}}}{\partial L_{q j k}} & =\frac{w_{q j k}}{L_{q j k}}\left[s_{q j k}\left\{\frac{1}{\delta}+I^{*}-\frac{1}{s_{q}}\left(\frac{1}{\delta}-\frac{1}{\rho}\right)-\frac{1}{s_{q j}}\left(\frac{1}{\rho}-\frac{1}{\sigma_{q}}\right)\right\}-\frac{1}{\sigma_{q}}\right], \\
\frac{\partial Y_{L q j k}}{\partial L_{i j k^{\prime}}} & =\frac{w_{q j k}}{L_{i j k}}\left[s_{q j k^{\prime}}\left\{\frac{1}{\delta}+I^{*}-\frac{1}{s_{q}}\left(\frac{1}{\delta}-\frac{1}{\rho}\right)-\frac{1}{s_{q j}}\left(\frac{1}{\rho}-\frac{1}{\sigma_{q}}\right)\right\}\right], \\
\frac{\partial Y_{L q j k}}{\partial L_{i j^{\prime} m}} & =\frac{w_{q j k}}{L_{q j^{\prime} m}}\left[s_{q j^{\prime} m}\left\{\frac{1}{\delta}+I^{*}-\frac{1}{s_{q}}\left(\frac{1}{\delta}-\frac{1}{\rho}\right)\right\}\right], \\
\frac{\partial Y_{L q j k}}{\partial L_{q^{\prime} n m}} & =\frac{w_{q j k}}{L_{q^{\prime} n m}}\left[s_{q^{\prime} x m}\left\{\frac{1}{\delta}+I^{*}\right\}\right],
\end{aligned}
$$

where $k \neq k^{\prime}, j \neq j^{\prime}$ and $q \neq q^{\prime}$, and $s_{q j k}, s_{q j}$ and $s_{q}$ denote the share of wages paid to workers in the respective cell of the labor market in the total wage bill. The index function $I^{*}$ is

$$
I^{*}= \begin{cases}\alpha-1 & \text { in the short run } \\ 0 & \text { in the long run }\end{cases}
$$

which follows from the production function if physical capital is fixed in the short run, i.e., if $K=\bar{K}$, and if the capital-output ratio is constant in the long-run, i.e, if $\kappa=\bar{\kappa}$.

Using the wage-setting equation in (3) we can write 


$$
\frac{\partial \mathbf{f}}{\partial \mathbf{u}} \frac{\partial \mathbf{u}}{\partial \mathbf{L}}=\left[\begin{array}{lllll}
\frac{\partial f_{111}}{\partial u_{111}} \frac{\partial u_{111}}{\partial L_{111}} & \cdots & 0 & \cdots & 0 \\
\vdots & \ddots & & & \vdots \\
0 & & \frac{\partial f_{i j k}}{\partial u_{i j k}} \frac{\partial u_{i j k}}{\partial L_{i j k}} & & 0 \\
\vdots & & & \ddots & \vdots \\
0 & \cdots & 0 & \cdots & \frac{\partial f_{342}}{\partial u_{342}} \frac{\partial u_{342}}{\partial L_{342}}
\end{array}\right]
$$

and

$$
\frac{\partial \mathbf{f}}{\partial \mathbf{u}} \frac{\partial \mathbf{u}}{\partial \mathbf{N}} \frac{d \mathbf{N}}{d M}=\left[\begin{array}{l}
\frac{\partial f_{111}}{\partial u_{111}} \frac{\partial u_{111}}{\partial N_{111}} \frac{d N_{111}}{d M} \\
\vdots \\
\frac{\partial f_{i j k}}{\partial u_{i j k}} \frac{\partial u_{i j k}}{\partial N_{i j k}} \frac{d N_{i j k}}{d M} \\
\vdots \\
\frac{\partial f_{342}}{\partial u_{342}} \frac{\partial u_{342}}{\partial N_{342}} \frac{d N_{342}}{d M}
\end{array}\right]
$$

Substituting the matrices (A.1), (A.2), and (A.3) into equation (6) yields the marginal employment response to immigration for the two cases of a fixed capital stock or a constant capital output ratio. 


\section{B Data Annex (not for publication)}

\section{B.1 Labor market and immigration data}

The labor market and immigration data which we use for our empirical analysis are taken from three data sets: the Integrated Database for Labor Market Research (IDA) in Denmark, the Integrated Employment Biographies (IEB) database in Germany, and the UK Quarterly Labour Force Survey (UK LFS).

As outlined in Section 3 of the main text, the IDA is compiled from a variety of sources such as the population register, the labor force and unemployment registers and administrative tax data (Statistics Denmark, 2007). It covers the entire population including all employed and unemployed persons. Immigrants can be identified both by their country of birth and citizenship. We use the 1993-2009 period for our analysis.

The IEB is a $5 \%$ random sample of all employees registered with the social security system, and of all unemployment benefit recipients in Germany. Self-employed individuals and civil servants who are not obliged to pay social security contributions (Beamte) are not included in the data set. As with the IDA, the IEB is compiled from a variety of administrative data sources which comprise, inter alia information on employment histories provided by the German pension system and on unemployed benefit recipients provided by the Federal Employment Services (Dorner et al., 2010). Due to the German jus sanguis tradition, the data set identifies foreigners only by citizenship. We use the 1993-2010 period for our analysis (in the estimation of the wage-setting curves: 19932009).

Administrative data on earnings in the UK are not available to researchers. The largest survey which contains information on migration status is the UK Labour Force Survey, ${ }^{21}$ a quarterly random sample of 60,000 households. Each quarter of the LFS sample is made up of five waves, each of approximately 12,000 households. Each wave is interviewed in five successive quarters. As a result, there is an $80 \%$ overlap in the samples for successive quarters. The UK LFS contains information on wages, qualification, occupational status, unemployment, the country of birth of foreigners as well as information on citizenship. Wage information is not available before 1993, so we use the 1993-2010 period in our analysis (in the estimation of the wage-setting curves: 1993-2009). Building on these data sources, we used the following classifications and definitions for our empirical analysis (see Table 10 for an overview).

1. Definition of foreigners: In Denmark foreigners are restricted to first generation immigrants. A first generation immigrant is defined as an individual who was born

\footnotetext{
${ }^{21}$ The Annual Survey of Hours and Earnings (ASHE) provides a larger sample size, but no information on nationality or country of birth.
} 


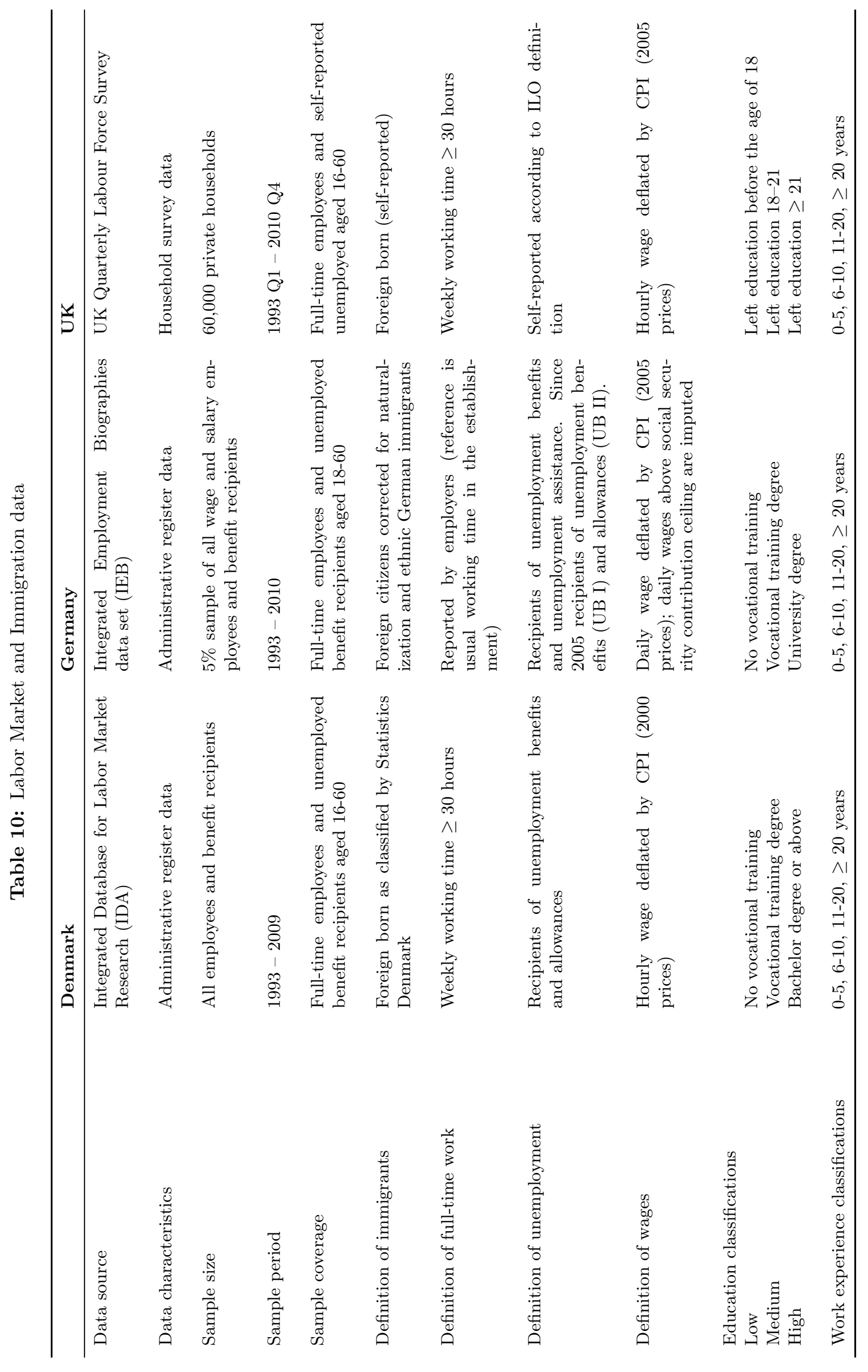


outside Denmark, and who has foreign-born parents or parents with foreign citizenship. If information on one of the parents is missing but the other parent fulfills the criteria, the individual is also defined as an immigrant. If there is no information on either of the parents then the individual is defined as a first generation immigrant if he or she is born outside Denmark.

The German data set provides no information on when immigrants entered the country or their country of birth. Due to the jus sanguinis tradition of German law, naturalization rates have been traditionally low, but increased slightly after the reform of the immigration act in 1999. To mitigate the possible effects of naturalization, we have classified all individuals as foreigners who are reported as foreign citizens in their first available spell since 1975. This prevents naturalization from being displayed as a declining foreigner share in our sample.

Moreover, since German law regards ethnic German immigrants (Spätaussiedler) as German citizens, the number of immigrants is likely to be underreported in the IEB. Using information from the benefit recipient file we are able to identify the majority of the ethnic German immigrants by their participation in language courses and other integration measures especially designed for this group. In our sample, the cumulative inflow of ethnic Germans accounts for more than 3 percent of the German labor force.

In the UK LFS individuals report whether they are born outside the UK. The same is true for citizenship.

Even after correcting for naturalization and the immigration of ethnic Germans, the definition of foreigners in the German data still differs from that in the Danish and the UK data sets, since second and third generation immigrants appear as foreign citizens in the German data set. As a robustness check, we have created also data sets where foreigners are defined by citizenship in Denmark and in the UK. It turns out that our results are qualitatively robust to the different definition of the foreign workforce.

2. Definition of the employed and unemployed labor force: In Denmark and the UK we consider males and females aged between 16 and 60; in Germany we restricted our sample to the labor force aged between 18 and 60 (see below). All samples consists of wage and salary full-time employees and unemployed persons. We exclude part-time workers, since the German IEB data set provides only wage information on a daily basis and hourly wages for part-time workers with few hours are usually known as of bad quality in Denmark. Full-time employment is defined by 30 working hours or more in Denmark and the UK. In Germany, employers are obliged to report workers as full time if the contracted agreed working time equals the usual working time in the establishment.

Self-employed persons are excluded, since we have no information on the self-employed 
in the German data set and no comparable income information of self-employed are available in Denmark and the UK. We include employees in the public sector, with the exception of workers who do not pay social security contributions ('Beamte' and marginal employed workers) in Germany.

The definition of unemployment varies slightly across the data sets. While the UK LFS employs the ILO definition, the register data in Denmark classifies the recipients of unemployment benefits and unemployment allowances as unemployed. In Germany, the recipients of insurance-based unemployment benefits I and the recipients of the mean-tested unemployment benefits II (until 2004 unemployment assistance) are defined as unemployed. The 2004 reform of the social security system in Germany involves an unavoidably structural break in 2005, which increased the number of unemployed particularly among the younger cohorts as they became eligible for unemployment benefits II without any prior employment experience. In order to alleviate that problem we have excluded persons aged below 18 in the German sample.

3. Definition of wages: In Germany, the wage information in the IEB is used to calculate social security contributions and is therefore highly reliable. The daily income is measured in Euro and is right-censored since gross wages can only be observed up to the social security contribution ceiling. About 9 percent of the employment spells in the final data set are right-censored. This may affect the estimation of the wagesetting curve in the high-skilled segments of the labor market. We have therefore imputed wages above the social security contribution ceiling using a heteroscedastic single imputation approach specifically developed for the IEB data set Büttner and Rässler (2008). In Denmark the gross hourly wage is measured in DKK. In the UK information on earnings is only available in interview wave 5 (up to 1996) and in waves 1 and 5 from 1997 onwards. We use reported gross hourly pay which is either directly reported or calculated as gross weekly pay in the main job divided by usual weekly hours worked in the main job.

4. Classification of education groups: In all three countries we distinguish three education groups: high, medium and low. This sets our paper apart from the approach of Katz and Murphy (1992), Card and Lemieux (2001) and Card and Schleifer (2009) which distinguish only two education classes (tertiary and secondary) as well as from the approach of Borjas (2003) and Ottaviano and Peri (2012), which employ four groups (college, college drop-outs, high-school and high-school-drop outs). In our view a distinction of education levels in university degrees, vocational training degrees and skilled workers with equivalent qualification levels, and workers without a vocational training degree or equivalent degrees is more suitable for the conditions in European labor markets.

In Denmark low skilled workers are defined as those who left school without any 
further education, medium skilled workers have a vocational training degree and high skilled workers hold at least a bachelor degree. In the German and UK data set information on the qualification of the foreign workforce is often missing.

In Germany, we imputed the missing information on education by employing a procedure especially developed for the data set by (Fitzenberger et al., 2006), which allows inconsistent education information to be corrected over time as well. After applying this imputation procedure, we had to drop about 4 percent of the individuals due to missing or inconsistent information on education.

In the UK information on qualification levels of foreigners display either high missing rates or a large share of the foreign workforce is placed in the "other qualifications" category, even though these workers may have a rather high level of education (see the evidence provided by Saleheen and Shadforth 2006). We therefore followed the procedure applied by Manacorda et al. (2012) and used the information on age left school to classify education groups. This enables us to circumvent the problem of missing information on the highest qualification degree.

We define a low level of education if an individual leaves school at an age of 17 or below, a medium level of education if an individual leaves school at an age between 18 and 20, and a high level of education if they leave school at an age of 21 or more. These three groups capture the three basic levels of educational qualification in the UK, namely GCSE, A-level and university degree. Other studies have tended to define "low-skilled" as those who leave school before the age of 16, but, since the 1970s, the majority of school-children in the UK were required to stay at school until they were 16 (the exception was for those born late in the academic year). For UK born workers, we can compare the highest educational qualification across these three groups. $23 \%$ of the low-skilled sample report having no qualifications, compared to $2 \%$ of the middle-skilled sample and $0.35 \%$ of the high-skilled sample.

5. Classification of experience groups: In all three data sets we distinguish four groups of work experience: 0 to 5 years, 6 to 10 years, 11 to 20 years, and more than 20 years. This assures that we have sufficient observations in each group in all three data sets.

\section{B.2 Control variables}

The estimates of the wage-setting curves and of the elasticities of substitution consider a number of variables which control for macroeconomic shocks and other influences at the aggregate level. The estimates of the wage-setting curves control for real GDP growth measured at constant prices, the annual inflation rate (measured as the GDP deflator) and the export propensity rate. The export propensity rate is measured as the ratio between exports and GDP. In estimating the elasticities of substitution we use time fixed effects to 
control for macroeconomic shocks and other aggregate effects. Definitions of the variables and data sources are displayed in Table 11.

\section{B.3 Instrumental variables}

As outlined in Section 4, we use an industry mix variable and an export demand index as instrumental variables in the wage-setting equations. The industry mix variables measures how much of the deviation in employment growth in an education-experience cell from the average employment growth can be explained by the concentration of workers in the respective cell in fast- or slow-growing industries. This variable simply measures how much of the change in employment can be attributed to an exogenous shift of the sectoral structure, for example due to technological change (Bartik, 1991). It is calculated as

$$
\text { indumix }_{q j}=\sum_{h=1}^{n} g_{h t} \frac{L_{q j h, t-1}}{L_{q j, t-1}}-g_{t}
$$

where $g_{h t}$ is the employment growth rate in industry $h$ in year $t, L_{q j h, t-1}$ is the employment of education-experience group $q j$ in industry $h$ in year $t-1, L_{q j, t-1}$ is the aggregate employment of education-experience group $q j$ in year $t-1$, and $g_{t}$ the average overall employment growth rate in year $t$. The summation is over all two digit, non-agricultural, private-sector industries in the UK and Denmark and over all manufacturing industries in Germany.

The export demand variable should capture the size of external demand and is calculated as the GDP of all trading partners in the OECD at constant prices weighted by their average share in exports of the respective country during the sample period (in constant USD in DK and the UK, in constant national currency at PPP in DE).

In the labor demand equations we use the following instruments as approximations for the reservation wage: first, the average number of dependent children in each cell of the labor market. The definition of the age groups vary across countries due to different systems of schooling and child care. Second the ratio of the average income of unemployed households to that of employed households in each cell of the labor market. Third, the mean average tax burden. Fourth, an income satisfaction index. Finally, the minimum wage in the UK.

Definitions of the variables and the data sources are presented in the bottom panel of Table 11. 


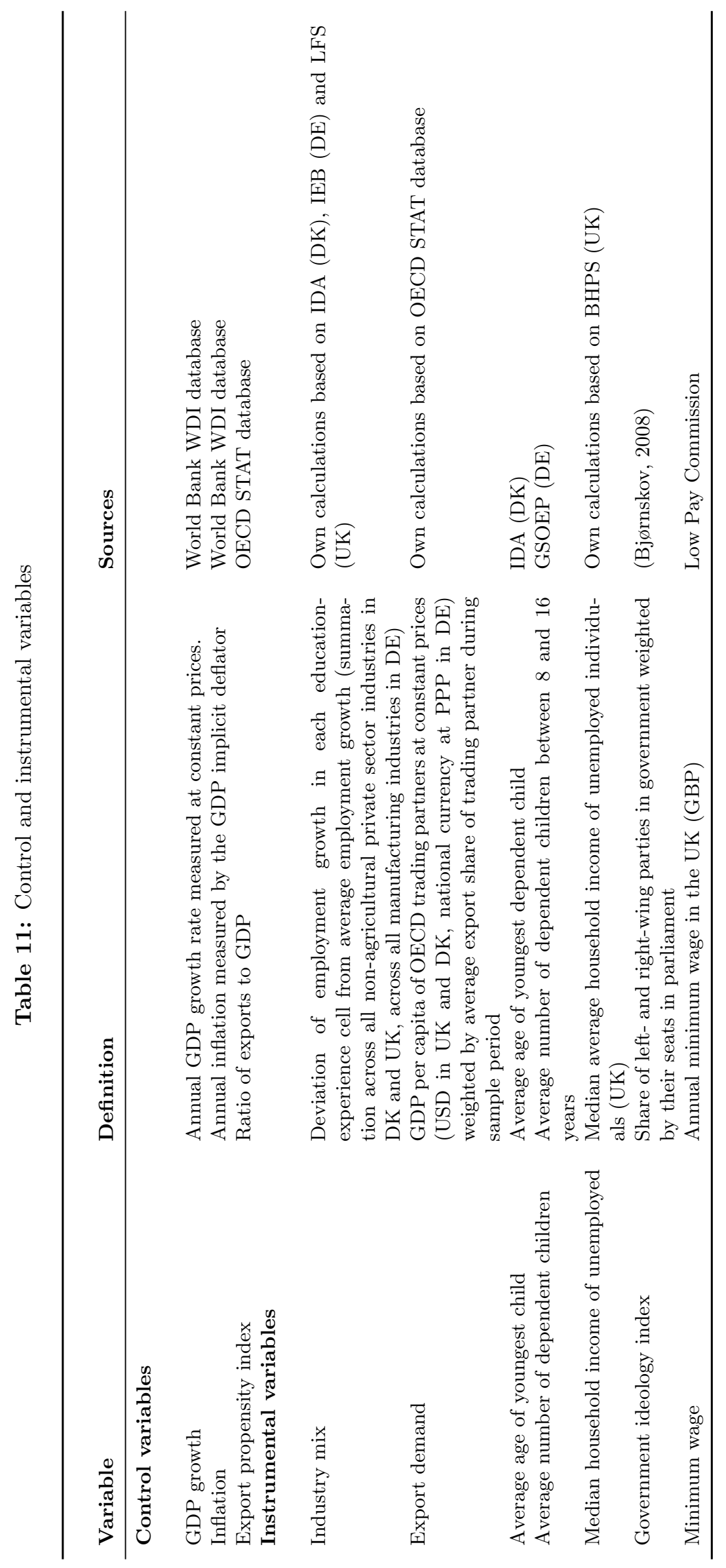

